\title{
The Effects of Housing Prices and Monetary Policy in a Currency Union
}

Oriol Aspachs-Bracons and Pau Rabanal 


\title{
IMF Working Paper
}

Research Department

\section{The Effects of Housing Prices and Monetary Policy in a Currency Union ${ }^{1}$}

\author{
Prepared by Oriol Aspachs-Bracons and Pau Rabanal
}

Authorized for distribution by Gian Maria Milesi-Ferretti

January 2011

\begin{abstract}
This Working Paper should not be reported as representing the views of the IMF. The views expressed in this Working Paper are those of the author(s) and do not necessarily represent those of the IMF or IMF policy. Working Papers describe research in progress by the author(s) and are published to elicit comments and to further debate.

The recent boom-and-bust cycle in housing prices has refreshed the debate on the drivers of housing cycles as well as the appropriate policy response. We analyze the case of Spain, where housing prices have soared since it joined the EMU. We present evidence based on a VAR model, and we calibrate a New Keynesian model of a currency area with durable goods to explain it. We find that labor market rigidities provide stronger amplification effects to all type of shocks than financial frictions do. Finally, we show that when the central bank reacts to house prices, the non-durable sector suffers an important contraction. As a result, the boom-and-bust cycle would not have been avoided if Spain had remained outside the EMU during the 1996-2007 period.

JEL Classification Numbers: E44; E52, F41.

Keywords: Housing, Monetary Policy, Financial Constraints. Author's E-Mail Address: oaspachs@lacaixa.es; prabanal@imf.org

\footnotetext{
${ }^{1}$ This paper is forthcoming in the International Journal of Central Banking. We thank Jordi Galí, Robert King (our discussant) and two anonymous referees for useful comments. This paper should not be reported as reflecting the views of Caixa d'Estalvis i Pensions de Barcelona ("la Caixa") or of the International Monetary Fund. Any errors and omissions are our own. Oriol Aspachs-Bracons is an economist at Caixa d'Estalvis i Pensions de Barcelona. Pau Rabanal is an economist at the International Monetary Fund's Research Department.
} 


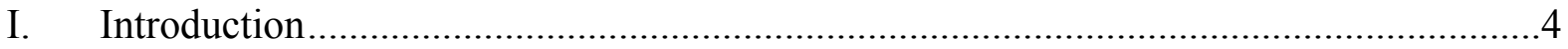

II. The VAR Response to Housing Demand and Interest Rate Shocks................................6

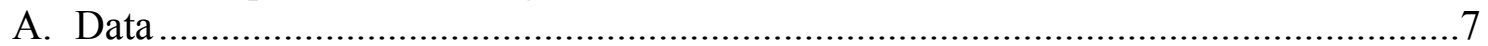

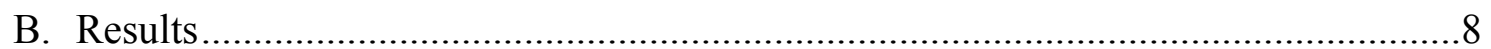

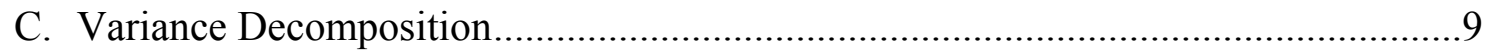

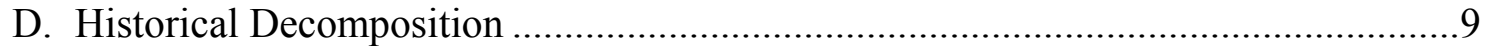

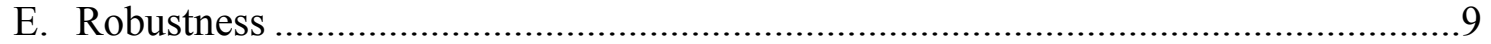

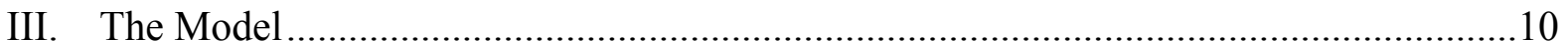

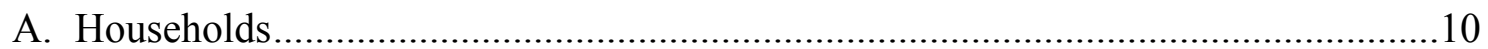

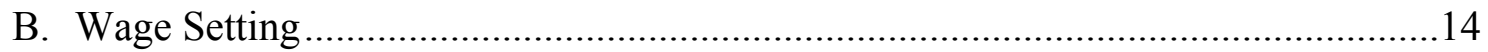

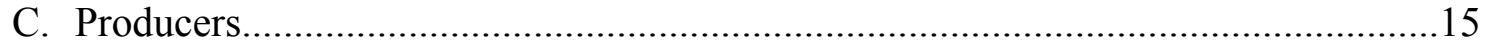

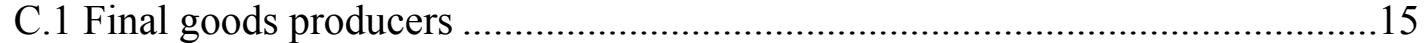

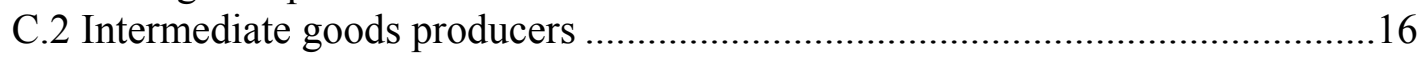

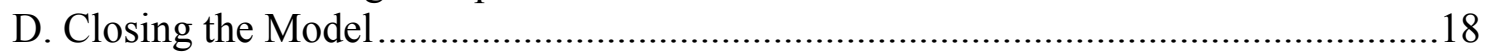

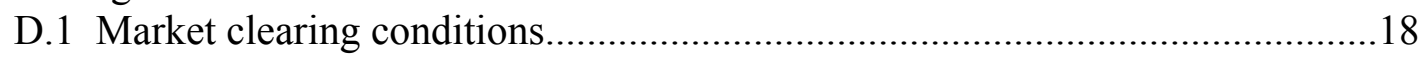

D.2 Monetary policy rule ...............................................................................19

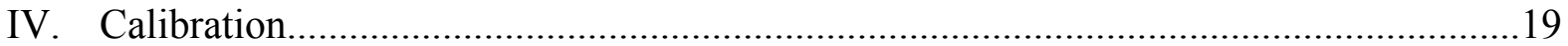

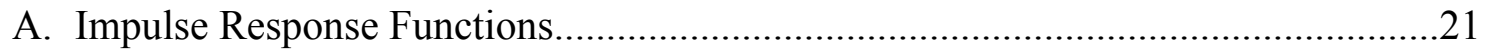

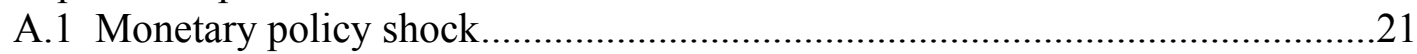

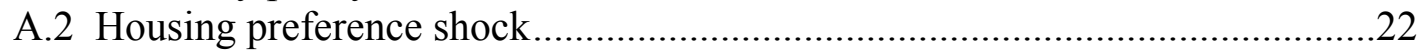

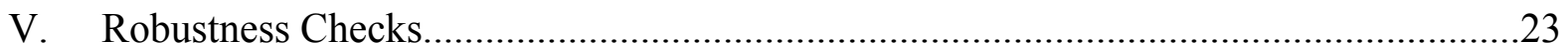

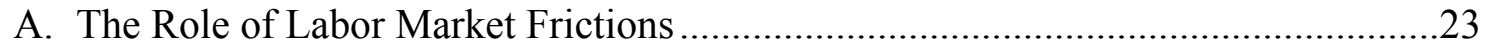

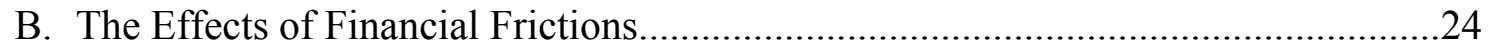

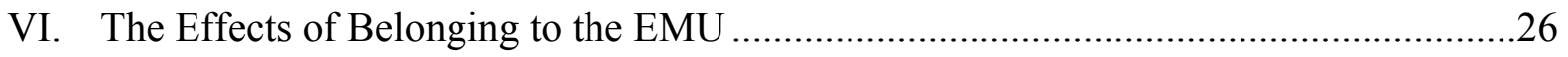

A. Impulse Response from The Model.................................................................2

B. Counterfactual Simulation of The Model .............................................................28

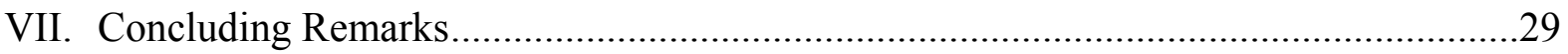

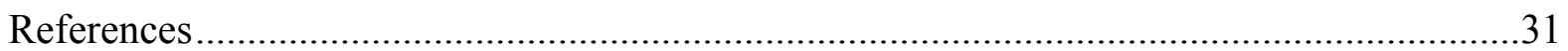

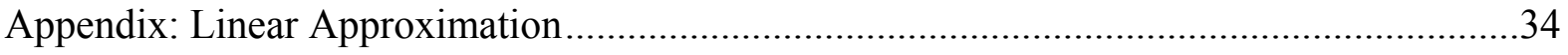

Text Table

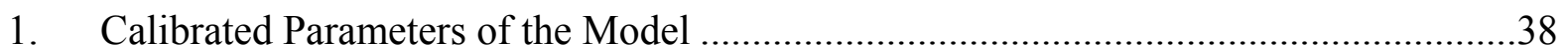

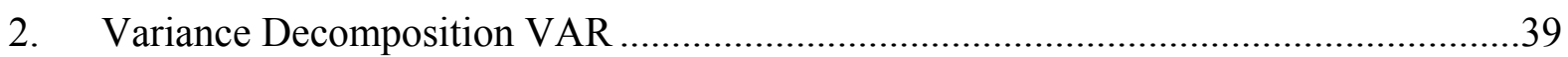

Figures

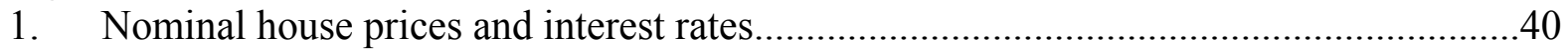

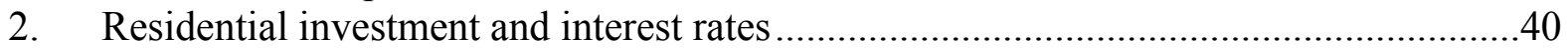




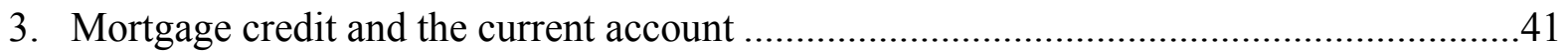

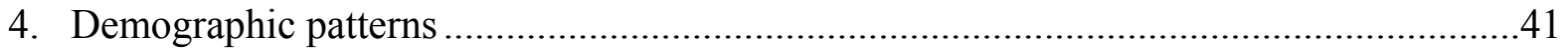

5. Impulse response from VAR, monetary policy shock ................................................42

6. Impulse response from VAR, housing demand shock.................................................43

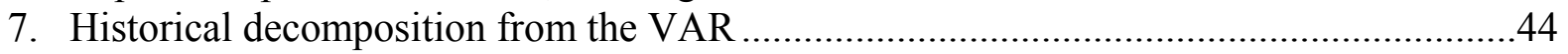

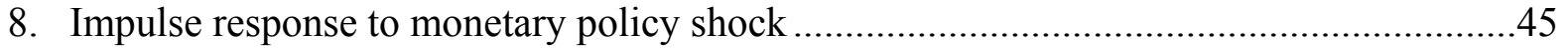

9. Impulse response to a housing preference shock ......................................................46

10. Impulse response to a monetary shock. The role of labor market frictions ......................47

11. Impulse response to a housing preference shock. The role of labor market frictions .......48

12. Impulse response to a monetary shock. The role of financial frictions ...........................49

13. Impulse response to a housing preference shock. The role of financial frictions ..............50

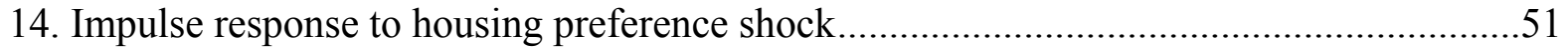

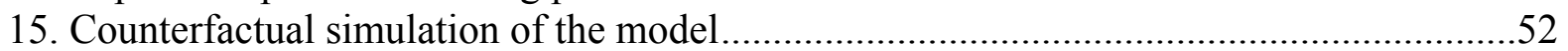




\section{Introduction}

The recent boom and bust cycle in housing prices in many advanced economies has refreshed the debate on the drivers of housing cycles and the role of the housing sector in amplifying economic volatility, as well as the appropriate response of the monetary authorities. The case of Spain is of special interest since its recent economic expansion has been characterized by sustained growth of residential investment, private consumption, credit and housing prices for more than a decade. Moreover, during this period nominal and real interest rates fell to exceptionally low levels during the convergence period in order to enter the european Economic and Monetary Union (EMU). As a result, a large current account deficit emerged, reaching almost 10 percent of GDP at the peak of the cycle in 2007.

In addition to growing external imbalances, a special source of concern for the Spanish economy was the loss of monetary policy autonomy after entering the EMU. In countries with their own national currency and monetary policy, such as the US, the UK, Australia and New Zealand, the central bank can increase interest rates to slow down the growth rate of housing prices (although in practice they were not successful in doing so in the most recent cycle), and also respond to a housing price collapse. ${ }^{1}$ However, Spain belongs to the EMU, and the European Central Bank sets rates according to the inflation rate of the Harmonized Index of Consumer Prices (HICP) of the Euro area as a whole. This means that monetary policy cannot be the first line of defense in response to negative sector- and country-specific shocks.

The recent evolution of the Spanish economy since 1996, including the housing market boom-bust cycle, is shown in Figures 1 through 4. Spain suffered from two developments going to the EMU: a loss of monetary autonomy and a large decline in interest rates. The period of convergence to and adoption of the euro (1996-2007) was also characterized by increased residential investment and house price growth rates. The demand for housing was further increased by the high levels of immigration and the baby boom generation (which peaked in the early 1970s in Spain) turning into adulthood, fuelling residential investment and even further increasing house prices. This increase in housing prices raised wealth and borrowing capacity of house owners who, in principle, could use these mechanisms to finance other consumption. ${ }^{2}$ The growing current account deficit is the other indicator of the magnitude of the consumption and borrowing boom, and the large

\footnotetext{
${ }^{1}$ Mishkin (2007) suggested that in response to a 20 percent housing price drop in the United States, the Federal Reserve should cut interest rates between 75 and 175 basis points, depending on the assumptions about the transmission mechanism.

${ }^{2}$ However, we should note that estimates of the marginal propensity to consume out of housing wealth in Spain are lower than in other countries. Bover (2005) obtains estimates of about 0.01-0.02.
} 
savings-investment imbalance was financed from abroad. Since late-2007, the boom cycle has turned into a bust.

Hence, in this paper we study the response of a small economy in a currency union (such as the Spanish one) to fluctuations in housing prices and residential investment. First, we present VAR evidence that shows the response of private consumption, residential investment, aggregate GDP, and real house prices to an interest rate shock and to a housing demand shock. We show that a decrease of interest rates and a positive housing demand shock lead to a rise in both final consumption and residential investment, a finding labelled as "comovement" in the literature when studying US data.

We rationalize our findings by building a two-country, two-sector model of a currency union in the spirit of Benigno (2004) and Rabanal (2009). The model includes durable and non-durable goods. Holding durables (i.e. housing) not only provides utility to the consumer but is also a vehicle for savings. In addition, the international dimension of the model implies that the savings and investment balance need not hold period per period at the country level. This will allow us to explain how increased credit demand in one country of a currency union can be met through funds coming elsewhere in the union. We calibrate the model, and examine the reaction of domestic variables and the nominal interest rate to a monetary policy shock and a demand/preference shock in the durable sector. Overall, the demand shock and the interest rate shock produce effects on the main aggregates of the economy similar to the ones observed in the VAR.

Then, we conduct a robustness exercise to understand how important are labor market and credit market rigidities in understanding the transmission of housing demand and monetary shocks in the economy. As opposed to the existing literature that stresses the role of financial frictions and borrowing constraints to explain comovement, we find that the effect of labor market rigidities has important implications for the persistent response of variables to shocks, and to explain the comovement between consumption and residential investment. Financial frictions amplify the monetary and preference shocks, but their quantitative effects are rather small when compared with a model with homogeneous agents and no credit constraints (but with labor market frictions). This does not mean credit constraints are not important. But they need to be modelled in a different way than has been included in the literature. One avenue to study would be to allow agents to borrow against their labor income, in addition to housing collateral.

In the last section of the paper we study the policy options for a small open economy such as the Spanish one, that faces large sector-specific shocks. In addition to our benchmark currency union model, we consider two additional cases. In the first one, we assume that Spain follows a Taylor rule which is similar to the one 
followed by the rest of the EMU. In the second case, we examine what would have happened if the Spanish authorities, outside the euro, had tried to "lean against the wind" and included house price inflation in their reaction function. We find that if Spain had followed an inflation targeting regime with a pure floating exchange rate, the monetary policy reaction to a domestic demand shock would not have been very different than that of belonging to a currency union. If we allow the central bank to react to house prices, the initial boom in housing inflation and residential investment can be reduced. However, to achieve stability in the housing market using the nominal interest rate as a policy tool leads to an important and persistent contraction in the non-durable sector. Hence, even if the Spanish authorities had kept monetary policy management, it is not clear that they would have chosen to "lean against the wind". It is important to note that this paper studies the 1996-2007 period, and the exercise only focuses on the possible costs of not being able to address demand-specific shocks in one sector or country using monetary policy. We show that these costs are small. Our model does not evaluate other important costs of not belonging to the EMU such as those associated with exchange rate volatility (e.g. higher domestic interest rates and lower international trade) which could affect growth.

The rest of the paper is organized as follows. In section II, we present some VAR-based evidence. In section III, we present the model, and in section IV we discuss at length the quantitative implications of the model. The robustness checks are presented in section $\mathrm{V}$ and in section VI we analyze the effects of belonging to the EMU. We leave section VII for concluding remarks.

\section{The VAR Response to Housing Demand and Interest Rate Shocks}

In this section, we present evidence on the response of main macroeconomic variables to housing demand and interest rate shocks with the help of a Vector Autoregressive (VAR) model. Several papers in the literature have studied the response of durable and non-durable consumption to a monetary policy shock using a VAR and the recursive identification scheme of Christiano, Eichenbaum, and Evans $(1999,2005)$. This approach consists of identifying the effect of the monetary policy shock by using the Cholesky decomposition of the variance-covariance matrix of the reduced form residuals of the VAR. Papers following this approach include Erceg and Levin (2006) and Monacelli (2009).

In addition, we seek to identify a housing demand shock from the VAR. We do so by assuming that the housing demand shock affects the real price of housing within a period, but it does not affect its quantity: in the short run the supply of housing is fixed, and demand shocks must be absorbed via price movements. In practice, this 
shock leads to an increase of residential investment and prices, thereby confirming our labeling. In the last part of the section, we discuss several robustness results that include: introducing euro area variables into the system, extending the sample period, and using sign restrictions to identify the housing demand shock.

We estimate the following VAR using $k$ variables:

$$
Y_{t}=C+\sum_{j=1}^{L} A_{j} Y_{t-j}+B u_{t}
$$

where $Y_{t}$ is a $k x 1$ vector of observable variables, $C$ is a $k x 1$ vector of constants, $A_{j}$ are $k x k$ matrices that collect the effect of endogenous variables at lag $j$ on current variables, $L$ is the lag length in the VAR, $B$ is a $k x k$ lower triangular matrix with diagonal terms equal to unity, and $u_{t}$ is a $k x 1$ vector of zero-mean, serially uncorrelated shocks with diagonal variance-covariance matrix.

The vector of endogenous variables is divided as follows: $Y_{t}=\left[\begin{array}{lll}Y_{1 t} & R_{t} & Y_{2 t}\end{array}\right]^{\prime}$, where $Y_{1 t}$ is a group of macroeconomic variables predetermined when monetary policy decisions are taken, $R_{t}$ is a relevant interest rate, and $Y_{2 t}$ contains the variables affected contemporaneously by monetary policy decisions. As is customary in the literature, to identify the interest rate shock we place the nominal interest rate after the macroeconomic variables. On the other hand we assume that house prices can respond to changes in monetary policy within a period: as an asset price, housing prices are likely to respond contemporaneously to changes in the nominal interest rate, so we include them in $Y_{2 t}$. Hence, we identify the housing demand shock as the shock that affects housing prices within a period, after taking into account the effect that changes in the interest rate have on housing prices. ${ }^{3}$

\section{A. Data}

The vector of observable variables is divided the following way. In $Y_{1 t}$ we include: (i) real household consumption of final goods in Spain, (ii) real residential investment in Spain, and (iii) real GDP in Spain. We use as a relevant interest rate $\left(R_{t}\right)$ the reference interbank rate. Finally, we include in $Y_{2 t}$ real house prices in Spain. All variables are introduced in the VAR in levels after taking natural logarithms, except for the nominal interest rate that we introduce directly in levels.

Private consumption, residential investment and GDP come from Spanish national

\footnotetext{
${ }^{3}$ We have also estimated a VAR with the ordering $Y_{t}=\left[\begin{array}{ccc}Y_{1 t} & Y_{2 t} & R_{t}\end{array}\right]^{\prime}$ and the results are very similar to the ones we present.
} 
accounts data and are deflated by the Spanish GDP deflator. Nominal housing prices come from the OECD and are deflated by the HICP in Spain. In studies involving US data the Federal Funds rate is typically the variable used as an indicator of the stance of monetary policy, following the study of Bernanke and Blinder (1992). Spain relinquished its monetary policy autonomy when it joined the EMU January 1st, 1999, and hence a domestic reference rate is no longer available. We choose the 3-month interbank rate as the reference interest rate. From 1999 we use the 3-month Euribor rate, and before the EMU period we use the 3-month MIBOR rate (the Madrid Interbank rate). Note that because of this reason, we call our shock an interest rate shock rather than a monetary policy shock in the VAR.

The relevant interbank interest rate for mortgages in Spain is the 12-month rate. In practice, using the 3 -month or the 12 -month rate delivers the same results, since the reference rate set by the European Central Bank, the 3-month interbank rate and the 12-month interbank rate move very closely together. We estimate the VAR from 1997:01 to 2008:04 at a quarterly frequency, with 2 lags. While the euro was launched in 1999, monetary policy in Spain followed its european counterparts closely in 1997-1998, and this allows us to include 8 more observations in the system.

\section{B. Results}

In Figures 5 and 6 we present the impulse responses of the five variables to an increase in interest rates and a housing demand shock. We present the mean and 85 percent confidence bands. ${ }^{4}$ In order to better interpret the VAR evidence, we present impulse-responses to a 25 basis points interest rate shock and to a housing demand shock that increases residential investment by 10 percent in the second period (by construction, the housing demand shock only affects prices in the initial period). An interest rate shock of 25 basis points is followed by further increases in the interest rate, which leads to a decline of real consumption of 0.6 percent after 12 quarters and a decline of 2 percent of residential investment after 7 quarters. This higher responsiveness of durable consumption and residential investment has been found in other papers such as Erceg and Levin (2006) and Monacelli (2009). The increase in interest rates also leads to a decline of real house prices of 2 percent after 7 quarters.

On the other hand, the housing demand shock leads to an increase of real house prices of 8 percent and an increase of residential investment of 10 percent after one period. There are significant spillovers to the rest of the economy and both private consumption and real GDP increase by more than 1 percent after 10 quarters. These are the features that our model will reproduce, in particular the comovement

\footnotetext{
${ }^{4}$ Given the short sample, it is difficult to obtain significance at the conventional 95 percent interval.
} 
in the response of both private consumption and residential investment to shocks.

\section{Variance Decomposition}

The results of the variance decomposition are presented in Table 2. Since we attempt to identify the effects of interest rate and housing demand shocks, we present the fraction of the variance decomposition for these two shocks only, and assign the remaining share to the aggregate of the other unspecified three shocks in the VAR system. Housing demand shocks explain a small fraction of the variance decomposition of private consumption and real GDP at short horizons, but at longer horizons (starting at 10 quarters) their contribution rises to about 25 percent. Housing demand shocks explain a similar fraction of the variance decomposition of investment at both short and long horizons. Interest rate shocks explain an important part of the variance decomposition of real variables at long horizons, between 10 and 20 percent depending on the variable. Finally, both interest rates and house price variance decompositions are driven by their own shock at short horizons, but by the "other shocks" in the model (60 percent of the share) at longer horizons.

\section{Historical Decomposition}

Figure 7 presents the contribution of each shock in explaining the deviation of the actual data from the balanced growth path of the system in the absence of shocks. It becomes evident that most fluctuations are driven by the shocks that we do not attempt to identify in the VAR, but both monetary policy and housing demand shocks also played an important role. It is interesting to note that contractionary monetary policy shocks and negative housing demand shocks help explain the slowdown in 2002-2003. At the same time, both shocks, and in particular housing demand shocks, had a very strong effect in the most recent boom since 2004, fueling house prices, residential investment, private consumption, and real GDP.

\section{E. Robustness}

We have conducted several robustness exercises with our VAR-based evidence, which are not presented here to save space, but are available upon request. In the first extension, we include the Harmonized Index of Consumer Prices (HICP) inflation and real GDP growth in the euro area to control for the endogenous response of interest rates. In this case, we find that the qualitative results do not 
change. This suggests that, from the Spanish perspective, changes in interest rates can be seen as purely exogenous shocks. Second, we have also experimented by using the sample period 1980-2008. All the results are very similar to the ones presented here, except in the response of real house prices to a monetary policy shock, which is small and nonsignificant. Finally, we have used sign restrictions as in Uhlig (2005) and Cardarelli et al. (2009) to identify the effects of housing demand, housing supply and monetary policy shocks, and found that the main message of Figures 5 and 6 does not change.

\section{The Model}

The theoretical framework consists of a general equilibrium two country, two sector model in a single currency area. The countries are of size $n$ and $1-n$, and each of them produces two types of goods, durables and non-durables, under monopolistic competition and nominal rigidities. Only the non-durable goods are tradable.

Producers of the final durable good sell its product to domestic households only in each country, which allows them to increase their housing stock. For this reason, we use the terms "durable good production" and "residential investment" interchangeably throughout the paper.

Since our VAR analysis has only focused on the effects of monetary and demand shocks on the housing sector and the spillover effects to the macroeconomy, the model will only include these shocks, so we leave aside technology shocks in the current analysis. In what follows, we present the home country block of the model. The analogous foreign country variables will be denoted by an asterisk.

\section{A. Households}

Each household $j$ in the home country maximizes the following utility function:

$$
E_{0}\left\{\sum_{t=0}^{\infty} \beta^{t}\left[\gamma \log \left(C_{t}^{j}-\varepsilon C_{t-1}\right)+(1-\gamma) \xi_{t}^{D} \log \left(D_{t}^{j}\right)-\frac{\left(L_{t}^{j}\right)^{1+\eta}}{1+\eta}\right]\right\}
$$

where $C_{t}^{j}$ denotes consumption of non-durable goods, $D_{t}^{j}$ denotes consumption of durable goods and $L_{t}^{j}$ is the labor disutility index. $\xi_{t}^{D}$ is a housing preference shock, which follows an $\mathrm{AR}(1)$ process in logs. 
The utility function denotes external habit formation, as in Smets and Wouters (2003) and Iacoviello and Neri (2010). $\beta$ is the discount factor and $\eta$ is the inverse elasticity of labor supply. The parameter $\varepsilon$ denotes the importance of the habit stock, which is last period's aggregate consumption $\left(C_{t-1}\right)$. In addition, consumption of non-durables is an index composed of home and foreign consumption goods:

$$
C_{t}^{j}=\left[\tau^{\frac{1}{\iota_{C}}}\left(C_{H, t}^{j}\right)^{\frac{\iota_{C}-1}{\iota_{C}}}+(1-\tau)^{\frac{1}{\iota_{C}}}\left(C_{F, t}^{j}\right)^{\frac{\iota_{C}-1}{{ }^{\iota_{C}}}}\right]^{\frac{{ }^{\iota_{C}}}{{ }^{C} C^{-1}}} \text {, where } \iota_{C}>0
$$

and where $C_{H, t}^{j}$ and $C_{F, t}^{j}$ are, respectively, consumption of the home non-durable goods and consumption of foreign non-durable goods by the home agent. $\tau$ is the fraction of domestically produced non-durables at home. Finally, following Iacoviello and Neri (2010), we assume that there is imperfect substitutability of labor supply across sectors, such that the labor disutility index can be written as:

$$
L_{t}^{j}=\left[\alpha^{-\iota_{L}}\left(L_{t}^{C, j}\right)^{1+\iota_{L}}+(1-\alpha)^{-\iota_{L}}\left(L_{t}^{D, j}\right)^{1+\iota_{L}}\right]^{\frac{1}{1+\iota_{L}}}, \text { where } \iota_{L}>0
$$

and where $L_{t}^{i, j}$ denotes hours worked by household $j$ in each sector $i=C, D$. $\alpha$ is the economic size of each sector. This imperfect substitutability implies that there is a costly labor reallocation across sectors following a shock. Note that when $\iota_{L}=0$ the aggregator is linear in hours worked in each sector, so there are no costs of switching from working in one sector to the other. ${ }^{5}$

The budget constraint of the home agent, in nominal terms, is given by:

$P_{t}^{C} C_{t}^{j}+P_{t}^{D} I_{t}^{D, j}+P_{t}^{A} A_{t}^{j}+B_{t}^{j} \leq \tilde{R}_{t-1} B_{t-1}^{j}+\frac{W_{t}^{C} L_{t}^{C, j}}{X_{t}^{C}}+\frac{W_{t}^{D} L_{t}^{D, j}}{X_{t}^{D}}+\left(R_{t}^{A}+P_{t}^{A}\right) A_{t-1}^{j}+\Pi_{t}^{j}$

where $P_{t}^{C}$ and $P_{t}^{D}$ are the price indices of durable and non-durable goods, to be defined below, $W_{t}^{i}$ is the nominal wage in each sector $i=C, D$, and $B_{t}^{j}$ denotes non-contingent nominal assets that are traded among households across the monetary union, and that pays (or costs) a gross nominal interest rate $\tilde{R}_{t}>1$. Following Iacoviello and Neri (2010), $X_{t}^{j}$ denotes the mark up (due to monopolistic competition in the labor market) between the wage paid by intermediate firms and the wage that households receive (the details of the nominal rigidities in the labor market are discussed below). $\Pi_{t}^{j}$ denotes nominal profits, because firms are

\footnotetext{
${ }^{5}$ Labor market rigidities could be a proxy for other real rigidities, such as product market entry, that the model does not include.
} 
ultimately owned by households. $A_{t}$ denotes the level of land owned by households, which is purchased at a price $P_{t}^{A}$ and which is rented to durable intermediate goods producers at a rental rate of $R_{t}^{A}$.

$I_{t}^{D, j}$ denotes residential investment to increase the housing stock. We assume that the law of motion of the housing stock evolves as follows:

$$
D_{t}^{j}=(1-\delta) D_{t-1}^{j}+\left[1-S\left(\frac{I_{t}^{D, j}}{I_{t-1}^{D, j}}\right)\right] I_{t}^{D, j}
$$

where $\delta$ denotes the rate of depreciation of the housing stock and, following Christiano, Eichenbaum, and Evans (2005), we introduce an adjustment cost function, $S($.$) , which is convex (i.e. S^{\prime \prime}()>0$ ). Furthermore, in the steady state $\bar{S}=\bar{S}^{\prime \prime}=0$ and $\bar{S}^{\prime \prime}>0$. The aim of introducing this cost is to allow for the possibility that the model can generate hump-shaped responses of residential investment to shocks.

We assume that households in the home country have to pay a premium above the union-wide riskless nominal interest rate as the country's debt level as a percentage of GDP increases. This assumption is needed to obtain a well-defined steady state for the aggregate level of debt. ${ }^{6}$ The relevant interest rate for the home-country households and the union-wide interest are related as follows:

$$
\tilde{R}_{t}=R_{t}-\exp \left[\kappa\left(\frac{B_{t}}{P_{t} Y_{t}}-\frac{B}{P Y}\right)\right]-1
$$

where $P_{t}$ is the aggregate price level, to be defined below, and $Y_{t}$ is real GDP, also to be defined below. $R_{t}$ is the riskless interest rate and $\kappa$ is the risk premium elasticity. This risk premium depends on aggregate variables, such that each household takes this effect as given when choosing between consuming durables, non-durables, and saving. Note that the risk premium is declining in the net foreign asset position of the country as a percentage of GDP, $\frac{B_{t}}{P_{t} Y_{t}}$.

We can separate the household's decision in a two stage process. First, households choose the amount of labor to supply to each sector, and the consumption of durables and non-durables. Second, they allocate how much to spend on home and foreign produced goods, taking into account that,

\footnotetext{
${ }^{6}$ See Schmitt-Grohé and Uribe (2003).
} 


$$
P_{t}^{C} C_{t}=P_{H, t} C_{H, t}+P_{F, t} C_{F, t}
$$

where $P_{H, t}$ denotes the price of home non-durable consumption goods and $P_{F, t}$ the price of foreign non-durable consumption goods. The variables corresponding to the foreign country are denoted with an asterisk, but the prices of foreign non-durable consumption goods do not carry it because they are also set in euros, and there is no price discrimination across countries.

The first order conditions to the household problem are given by: ${ }^{7}$

$$
\begin{gathered}
U_{C_{t}}=\lambda_{t} P_{t}^{C} \\
U_{D_{t}}=\mu_{t}-\beta(1-\delta) E_{t} \mu_{t+1} \\
\lambda_{t} P_{t}^{D}=\mu_{t}\left\{1-S\left(\frac{I_{t}^{D}}{I_{t-1}^{D}}\right)-S^{\prime}\left(\frac{I_{t}^{D}}{I_{t-1}^{D}}\right) \frac{I_{t}^{D}}{I_{t-1}^{D}}\right\}+\beta E_{t} \mu_{t+1}\left[S^{\prime}\left(\frac{I_{t+1}^{D}}{I_{t}^{D}}\right)\left(\frac{I_{t+1}^{D}}{I_{t}^{D}}\right)^{2}\right] .
\end{gathered}
$$

Absent adjustment costs to residential investment, these three equations can be reduced to the following condition:

$$
\frac{P_{t}^{D}}{P_{t}^{C}}=\frac{1-\gamma}{\gamma} \frac{\xi_{t}^{D}\left(C_{t}-\varepsilon C_{t-1}\right)}{D_{t}}+\beta(1-\delta) E_{t}\left[\left(\frac{C_{t}-\varepsilon C_{t-1}}{C_{t+1}-\varepsilon C_{t}}\right) \frac{P_{t+1}^{D}}{P_{t+1}^{C}}\right]
$$

Note that if the durable good was in fact non-durable (i.e. $\delta=1$ ), this condition simply states that the marginal utilities of consumption should equal relative prices. Since the durable good has a residual value the following period, this induces the extra-term of holding an additional unit of the durable good.

A standard Euler equation for the consumption of non-durable goods is:

$$
1=\beta \tilde{R}_{t} E_{t}\left[\frac{P_{t}^{C}}{P_{t+1}^{C}}\left(\frac{C_{t}-\varepsilon C_{t-1}}{C_{t+1}-\varepsilon C_{t}}\right)\right] .
$$

\footnotetext{
${ }^{7}$ Since all households behave the same way, we drop the $j$ subscripts in what follows.
} 
A similar Euler equation for land is as follows:

$$
\tilde{R}_{t}=E_{t}\left(\frac{R_{t+1}^{A}+P_{t+1}^{A}}{P_{t}^{A}}\right)
$$

such that households are indifferent between investing in land and riskless bonds. The allocation of nondurable consumption expenditures between home and foreign-produced goods is:

$$
\begin{gathered}
C_{H, t}=\tau\left(\frac{P_{H, t}}{P_{t}^{C}}\right)^{-\iota_{C}} C_{t} \\
C_{F, t}=(1-\tau)\left(\frac{P_{F, t}}{P_{t}^{C}}\right)^{-\iota_{C}} C_{t} .
\end{gathered}
$$

The price index for non-durables is (the CPI):

$$
\left(P_{t}^{C}\right)^{1-\iota_{C}}=\left[\tau\left(P_{H, t}\right)^{1-\iota_{C}}+(1-\tau)\left(P_{F, t}\right)^{1-\iota_{C}}\right] .
$$

The utility maximization problem of foreign country households is quite similar. We assume that the functional forms for preferences are the same across countries, but allow for different parameter values. That is, $\gamma^{*}$ is the weight of non-durables in the utility function, and $\tau^{*}$ the fraction of domestically produced non-durables.

\section{B. Wage Setting}

Nominal wage stickiness is introduced as in Smets and Wouters (2007) and Iacoviello and Neri (2010), so we omit most functional forms here and refer the interested reader to those papers. Households supply homogeneous labor services to unions. These unions differentiate these labor services and set wages subject to a Calvo (1983)-type restriction, where the probabilities in each sector of not being able to readjust wages in a given period are $\theta_{C, W}$ and $\theta_{D, W}$. They offer these labor services to wholesale labor packers, who reassemble these services into homogeneous labor composites, which are in turn hired by intermediate firms from these packers.

Under Calvo wage setting and with partial indexation to past non-durable (CPI) inflation (with coefficients $\varphi_{C, W}$ and $\varphi_{D, W}$ ), the wage-setting equations can be loglinearized into the following wage Phillips curves, where lower case variables denote percent deviations from steady-state values: 


$$
\begin{gathered}
\omega_{t}^{C}-\omega_{t-1}^{C}+\Delta p_{t}^{C}-\varphi_{C, W} \Delta p_{t-1}^{C}=\beta E_{t}\left(\omega_{t+1}^{C}-\omega_{t}^{C}+\Delta p_{t+1}^{C}-\varphi_{C, W} \Delta p_{t}^{C}\right) \\
+\kappa^{C, W}\left[\frac{c_{t}-\varepsilon c_{t-1}}{1-\varepsilon}+[(\varphi-\iota) \alpha+\iota] l_{t}^{C}+(\varphi-\iota)(1-\alpha) l_{t}^{D}-\omega_{t}^{C}\right]
\end{gathered}
$$

where $\kappa^{C, W}=\frac{\left(1-\theta_{C, W}\right)\left(1-\beta \theta_{C, W}\right)}{\theta_{C, W}}$, and

$$
\begin{gathered}
\omega_{t}^{D}-\omega_{t-1}^{D}+\Delta p_{t}^{C}-\varphi_{D, W} \Delta p_{t-1}^{C}=\beta E_{t}\left(\omega_{t+1}^{D}-\omega_{t}^{D}+\Delta p_{t+1}^{C}-\varphi_{D, W} \Delta p_{t}^{C}\right) \\
+\kappa^{D, W}\left[\frac{c_{t}-\varepsilon c_{t-1}}{1-\varepsilon}+[(\varphi-\iota)(1-\alpha)+\iota] l_{t}^{D}+(\varphi-\iota) \alpha l_{t}^{C}-\omega_{t}^{D}\right]
\end{gathered}
$$

where $\kappa^{D, W}=\frac{\left(1-\theta_{D, W}\right)\left(1-\beta \theta_{D, W}\right)}{\theta_{D, W}}$.

\section{Producers}

There is a continuum of intermediate goods producers, indexed by $h \in[0, n]$ in the home country, and by $f \in[n, 1]$ in the foreign country, that are imperfect substitutes of each other, and that supply final goods producers in each sector. There is a continuum of final goods producers in the two sectors that operate under perfect competition and flexible prices. Producers of the final durable good sell their products to domestic households only in each country. Producers of the final non-durable good sell their products to domestic and foreign households. Hence, it is important to distinguish the price level of domestic non-durable consumption goods, $P_{H, t}$, which does not coincide with the price level of non-durables or CPI $\left(P_{t}^{C}\right)$ because of the presence of imported non-durable goods, whose price is $P_{F, t}$.

\section{C.1 Final Goods Producers}

In the durable sector, final goods producers purchase intermediate goods producers and aggregate them according to the following production function:

$$
Y_{t}^{D} \equiv\left[\left(\frac{1}{n}\right)^{\frac{1}{\sigma_{D}}} \int_{0}^{n} Y_{t}^{D}(h)^{\frac{\sigma_{D}-1}{\sigma_{D}}} d h\right]^{\frac{\sigma_{D}}{\sigma_{D}-1}}
$$

Profit maximization delivers the following demand for individual, intermediate 
non-durable goods:

$$
Y_{t}^{D}(h)=\left(\frac{P_{t}^{D}(h)}{P_{t}^{D}}\right)^{-\sigma_{D}} Y_{t}^{D}
$$

where the price level is given by imposing the zero-profit condition,

$$
P_{t}^{D} \equiv\left\{\frac{1}{n} \int_{0}^{n}\left[P_{t}^{D}(h)\right]^{1-\sigma_{D}} d h\right\}^{\frac{1}{1-\sigma_{D}}} .
$$

In the non-durable goods sector, expressions are similar but with an appropriate change of notation since the price level of domestic non-durables and of a basket of durables is not the same. The aggregate production function is:

$$
Y_{t}^{C} \equiv\left[\left(\frac{1}{n}\right)^{\frac{1}{\sigma_{C}}} \int_{0}^{n} Y_{t}^{C}(h)^{\frac{\sigma_{C}-1}{\sigma_{C}}} d h\right]^{\frac{\sigma_{C}}{\sigma_{C}-1}},
$$

individual intermediate non-durable goods demand is:

$$
Y_{t}^{C}(h)=\left(\frac{P_{t}^{H}(h)}{P_{t}^{H}}\right)^{-\sigma_{C}} Y_{t}^{C}
$$

where the price level is:

$$
P_{t}^{H} \equiv\left\{\frac{1}{n} \int_{0}^{n}\left[P_{t}^{H}(h)\right]^{1-\sigma_{C}} d h\right\}^{\frac{1}{1-\sigma_{C}}} .
$$

\section{C.2 Intermediate Goods Producers}

There is a continuum of intermediate goods producers, indexed by $h \in[0, n]$ in the home country, and by $f \in[n, 1]$ in the foreign country, that are imperfect substitutes of each other, and that supply final goods producers in each sector. Intermediate goods producers face a Calvo-type restriction when setting their price. In each period, a fraction $1-\theta_{i}$ in each sector $(i=C, D)$ receives a signal to reset prices optimally. In addition, a fraction $\phi_{i}(i=C, D)$ index their price to last period's sectorial inflation rate whenever unable to reoptimize. 
Intermediate nondurable goods in both countries are produced with labor:

$$
\begin{aligned}
& Y_{t}^{C}(h)=L_{t}^{C}(h), \text { for all } h \in[0, n], \\
& Y_{t}^{C}(f)=L_{t}^{C}(f), \text { for all } f \in[n, 1] .
\end{aligned}
$$

Intermediate goods in the durable sector are produced combining land and labor with the following Cobb-Douglas production function:

$$
\begin{aligned}
& Y_{t}^{D}(h)=\left(A_{t-1}\right)^{1-\alpha_{D}}\left[L_{t}^{D}(h)\right]^{\alpha_{D}}, \text { for all } h \in[0, n], \\
& Y_{t}^{D}(f)=\left(A_{t-1}\right)^{1-\alpha_{D}}\left[L_{t}^{D}(f)\right]^{\alpha_{D}}, \text { for all } f \in[n, 1],
\end{aligned}
$$

where $\alpha_{D}$ denotes the labor share in the housing sector. In the remaining part of this subsection, we work out the conditions for the home country firms' pricing decisions. In the nondurable sector, cost minimization implies that the real marginal cost of production equals the real wage:

$$
M C_{t}^{C}=\frac{W_{t}^{C}}{P_{t}^{C}} .
$$

In the durable sector, after imposing that the supply of land is fixed $\left(A_{t}=\bar{A}\right)$, the marginal cost is given by:

$$
M C_{t}^{D}=\frac{1}{\alpha^{D}} \frac{W_{t}^{D}}{P_{t}^{C}}\left(L_{t}^{D}\right)^{1-\alpha^{D}}(\bar{A})^{-\left(1-\alpha^{D}\right)},
$$

where we have substituted for the optimal expression of the rental rate of land: ${ }^{8}$

$$
R_{t}^{A}=\left(\frac{1-\alpha^{D}}{\alpha^{D}}\right) \frac{W_{t}^{D} L_{t}^{D}}{\bar{A}}
$$

Firms in the durable sector face the following maximization problem:

$$
\operatorname{Max}_{P_{t}^{D}(h)} E_{t} \sum_{k=0}^{\infty} \theta_{D}^{k} \Lambda_{t, t+k}\left\{\left[\frac{P_{t}^{D}(h)\left(\frac{P_{t+k-1}^{D}}{P_{t-1}^{D}}\right)^{\phi_{D}}}{P_{t+k}^{D}}-M C_{t+k}^{D}\right] Y_{t+k}^{D}(h)\right\}
$$

subject to future demand

${ }^{8}$ We choose the level of $\bar{A}$, such that the level of real wages is the same across sectors in the steady-state. 


$$
Y_{t+k}^{D}(h)=\left[\frac{P_{t}^{D}(h)}{P_{t+k}^{D}}\left(\frac{P_{t+k-1}^{D}}{P_{t-1}^{D}}\right)^{\phi_{D}}\right]^{-\sigma_{D}} Y_{t+k}^{D},
$$

where $\Lambda_{t, t+k}=\beta^{k} \frac{\lambda_{t+k}}{\lambda_{t}}$ is the stochastic discount factor, and $\lambda_{t}$ is the marginal utility of non-durable consumption.

The optimal choice is given by:

$$
\frac{\hat{P}_{t}^{D}}{P_{t}^{D}}=\frac{\sigma_{D}}{\left(\sigma_{D}-1\right)} E_{t}\left\{\frac{\sum_{k=0}^{\infty} \beta^{k} \theta_{D}^{k} \lambda_{t+k}\left(\prod_{s=1}^{k} \frac{\left(\Pi_{t+s-1}^{D}\right)^{\phi_{D}}}{\Pi_{t+s}^{D}}\right)^{-\sigma_{D}} M C_{t+k}^{D} Y_{t+k}^{D}}{\sum_{k=0}^{\infty} \beta^{k} \theta_{D}^{k} \lambda_{t+k}\left(\prod_{s=1}^{k} \frac{\left(\Pi_{t+s-1}^{D}\right)^{\phi_{D}}}{\Pi_{t+s}^{D}}\right)^{1-\sigma_{D}} Y_{t+k}^{D}}\right\}
$$

Given the assumptions about Calvo pricing, the evolution of the price level is:

$$
P_{t}^{D}=\left\{\theta_{D}\left[P_{t-1}^{D}\left(\Pi_{t-1}^{D}\right)^{\phi_{D}}\right]^{1-\sigma_{D}}+\left(1-\theta_{D}\right)\left(\hat{P}_{t}^{D}\right)^{1-\sigma_{D}}\right\}^{\frac{1}{1-\sigma_{D}}} .
$$

Firms in the non-durable sector face a similar maximization problem, and hence the optimal price and the evolution of the price level have similar expressions, with the appropriate change of notation.

\section{Closing the Model}

\section{D.1 Market Clearing Conditions}

In each intermediate good, supply equals demand. We write the market clearing conditions in terms of aggregate quantities. Hence, we multiply per-capita quantities by population size of each country. Total production in the non-durable sector is equal to total domestic consumption and exports:

$$
Y_{t}^{C}=n C_{H, t}+(1-n) C_{H, t}^{*}
$$

while residential investment is used to increase the domestic housing stock:

$$
Y_{t}^{D}=n\left[D_{t}-(1-\delta) D_{t-1}\right] .
$$


Total hours worked equals labor supply in each sector:

$$
\begin{aligned}
\int_{0}^{n} L_{t}^{C}(h) d h & =\int_{0}^{n} L_{t}^{C, j} d j \\
\int_{0}^{n} L_{t}^{D}(h) d h & =\int_{0}^{n} L_{t}^{D, j} d j .
\end{aligned}
$$

Market clearing in the international bonds market is:

$$
n B_{t}+(1-n) B_{t}^{*}=0
$$

Finally, the evolution of aggregate net foreign assets is:

$$
n B_{t}=n \tilde{R}_{t-1} B_{t-1}+(1-n) P_{H, t} C_{H, t}^{*}-n P_{F, t} C_{F, t} .
$$

\section{D.2 Monetary Policy Rule}

In order to close the model, we need to specify a rule for monetary policy, which is conducted by the European Central Bank with an interest rate rule that targets CPI inflation and also exhibits interest rate inertia:

$$
R_{t}=\left[\bar{R}\left(\frac{P_{t}^{E M U} / P_{t-1}^{E M U}}{\bar{\Pi}^{E M U}}\right)^{\gamma_{\Pi}}\right]^{1-\gamma_{R}} R_{t-1}^{\gamma_{R}} \exp \left(\varepsilon_{t}^{m}\right) .
$$

where the euro area CPI is given by a geometric average of the home and foreign country CPIs, using the country size as a weight:

$$
P_{t}^{E M U}=\left(P_{t}^{C}\right)^{n}\left(P_{t}^{C^{*}}\right)^{1-n}
$$

\section{Calibration}

In the steady state, we assume zero inflation, a trade balance of zero, and that the net international position of both economies is zero. Therefore, we only need to solve for the per-capita values of the home country, which are the same as those in the foreign country. We also assume that the degree of monopolistic competition in both types of goods is the same $\left(\sigma_{C}=\sigma_{D}=\sigma\right)$, and hence the ratio of prices is one. Now, we solve for the levels of consumption of durables, non-durables, hours, and the economic size of each sector. The optimal steady-state ratio of durable to non-durable consumption is:

$$
\frac{C}{D}=\frac{\gamma[1-\beta(1-\delta)]}{1-\gamma}=\Omega
$$


The fraction of spending allocated to non-durable consumption over total spending $(\alpha)$ is equal to:

$$
\frac{C}{C+\delta D}=\alpha
$$

Note that $\gamma$ and $\alpha$ cannot be calibrated independently. Given values for $\alpha, \delta$, $\beta$, we can solve for the value of $\gamma$ in the utility function.

To ensure that the level of real wages in both sectors is the same (despite different labor shares), we need to calibrate $\bar{A}=\left(\frac{1}{\alpha^{D}}\right)^{\frac{1}{1-\alpha_{D}} L^{D}}$. As a result, from the labor supply conditions by households,

$$
(1-\alpha) L^{C}=\alpha L^{D}
$$

which means that agents spend a fraction $\alpha$ of time working in the non-durable sector, and a fraction $1-\alpha$ in the durable sector.

Table 1 summarizes the values of the exogenous and endogenous parameters of the model. We set as the home country Spain, and the foreign country the rest of the EMU. Hence, we set the size of the home economy to $n=0.1$. We set the size of the construction sector at $1-\alpha=0.1$, both in Spain and in the EMU, which is roughly the average size for the value added of the construction sector in the last decade. We calibrate the bilateral trade parameter $(\tau)$ based on total imports from the EMU to Spain over total spending, and calibrate its analogous parameter in the $\operatorname{EMU}\left(\tau^{*}\right)$ in a similar way.

For the parameter capturing the debt elasticity to the domestic interest rate, the technology, preference and nominal rigidities parameters, we use the estimated values in a companion paper of ours. ${ }^{9}$ In that paper, we imposed the same parameter values across countries (except the bilateral imports ratio), so we follow this strategy here. Therefore, the value for $\kappa$ is fixed to 0.02 , which captures the idea that interest rates spreads between Spain and the EMU have been negligible during this period. In Aspachs-Bracons and Rabanal (2010), the posterior mean estimate for the labor market rigidities, $\iota_{L}$, is 1.2 , a value which is very similar to the one estimated by Iacoviello and Neri (2010) using US data. We also calibrate the degree of habit formation $\varepsilon$, the elasticity of labor supply $\eta$, the elasticity of substitution between home and foreign goods $\iota_{C}$, and the investment adjustment cost parameter $\psi$, from our companion paper.

Having calibrated the real side of the economy, we now proceed to discuss the

\footnotetext{
${ }^{9}$ In Aspachs-Bracons and Rabanal (2010), we use standard Bayesian methods to estimate a DSGE model similar to the one presented here for Spain and the rest of the EMU using data between 1995 and 2008 .
} 
calibration of the degree of nominal rigidity in each sector and country. In the literature, there is a long standing debate on the degree of nominal rigidities between housing and the other sectors of the economy, and how this might affect the transmission mechanism of monetary policy. For instance, Carlstrom and Fuerst (2007) use the evidence on frequency of price adjustments in the durable and non-durable sectors of Bils and Klenow (2004) to argue that prices in the housing sector are more flexible than in the consumption goods sector. Using this calibration is problematic because, in the model, a monetary contraction leads to an expansion of residential investment that is at odds with the data. This result arises because the differing degree of nominal rigidity across sectors causes a strong movement of relative prices.

We also use the values estimated in Aspachs-Bracons and Rabanal (2010) to calibrate the nominal rigidities. Hence, we set prices to be more sticky in the non-durable sector, $\theta_{C}=0.87$, than in durable goods, $\theta_{D}=0.34$. Nominal rigidities parameters are assumed to be the same between Spain and the rest of the EMU. ${ }^{10}$ We assume that the Calvo lotteries for wage setting imply average durations of wage contracts of one year $\left(\theta_{C, W}=\theta_{D, W}=0.75\right)$ and we also assume full indexation to last period's inflation, given the way wage contracts are set in Spain. ${ }^{11}$ Finally, we also calibrate the parameters of the Taylor rule according to the estimates in our companion paper.

\section{A. Impulse Response Functions}

In this section, we discuss the main features of the model by presenting the impulse response functions of a monetary policy shock and a housing preference shock. We obtain the model's dynamics by taking a log-linear approximation around the steady state. In Appendix A we detail the full set of linear equations of the model.

\section{A.1 Monetary Policy Shock}

Figure 8 presents the impulse response functions of the main variables in Spain to an expansionary monetary policy shock in the euro area. We choose the size of the shock $\varepsilon_{t}^{m}$ in the Taylor rule expression (33) to simulate an increase of 25 basis points

\footnotetext{
${ }^{10}$ Assuming that durable prices are flexible does not change the qualitative results of our analysis. Aspachs-Bracons and Rabanal (2010) use information contained in survey evidence for the euro area in, as explained in Fabiani et al. (2006), as priors.

${ }^{11}$ Smets and Wouters (2003) obtain a posterior mean of 0.66 for backward looking wage indexation in the euro area. Using this paramter value instead of full indexation does not change the results.
} 
on impact in the nominal interest rate. Following the shock, consumption of both good types declines. Similar to what we obtained in the VAR, the effect is quantitatively stronger in the durable sector, although we have trouble matching the long lags in the transmission mechanism present in the data. Note that we obtain a strong comovement between both sectors even though the degrees of nominal rigidity in price setting are different across sectors. Why is this the case? After a monetary policy tightening, and in response to lower demand, durable good producers can decrease prices faster than the non-durable producers and, hence, the relative price between durables and non-durables decreases (just as in the VAR-based evidence). Wage stickiness limits the degree to which real unit labor costs differ across sectors and, hence, the movement in relative prices is lower even under asymmetric nominal rigidities in price setting. ${ }^{12}$ In addition, costly labor reallocation limits the degree to which sectorial output can differ due to different labor inputs. Hence, as we discuss in the following section, labor market and wage rigidities are key to explaining the data.

\section{A.2 Housing Preference Shock}

Next, we examine the effects of a housing preference shock in Figure 9. In their study of the US economy, Iacoviello and Neri (2010) conclude that these type of shocks explain a significant fraction of the volatility of house prices and residential investment. Darracq-Parriès and Notarpietro (2009) reach a similar conclusion when looking at euro area data, and Aspachs-Bracons and Rabanal (2010) find a similar result when using data for Spain and the euro area. In the context of our model, one could see these demand pressures as stemming from population changes: increased immigration, the "baby boom" generation that in Spain peaked in the 1970s, and changes in social attitudes that reduce the number of persons per households and increase the number of household units.

The housing demand shock is normalized such that residential investment increases about 10 percent above its long-run value, and the shock has an $\mathrm{AR}(1)$ coefficient of 0.9. The preference shock in the durables sector also leads to an increase in the relative price of durables. ${ }^{13}$ Given the small size of the Spanish economy with respect to the Euro area, interest rates barely react to developments in the Spanish economy, allowing it to experience a long-lived expansion in this sector. Note also that non-durable output slightly increases with the housing demand shock, which

\footnotetext{
${ }^{12}$ Di Ceccio (2009) finds a similar result in a two-sector RBC model.

${ }^{13}$ Note that since the model solution is linear, the effects of the shock are proportional to the size of the shock. In a non-linear world, a shock that increases residential investment by 10 percent could have proportionally larger effects than a shock that increases investment by, let's say, 1 percent.
} 
coincides with the VAR evidence presented above. However, as in Iacoviello and Neri (2010), the positive response of non-durable consumption is quantitatively small. In the following subsection, we seek to understand which mechanism in the model generates the comovement between the two sectors.

\section{Robustness Checks}

As argued by Calstrom and Fuerst (2007) and Monacelli (2009), if prices are flexible in one sector but sticky in the other, then a monetary policy contraction will imply that output falls in the sticky price sector but will increase in the flexible price sector, contradicting VAR evidence using US data. These papers suggest that introducing credit constraints and/or labor market rigidities might help solve the comovement problem even under heterogeneous degrees of nominal rigidity. Hence, in this section we study how the impact of monetary and demand shocks changes for different degrees of labor market rigidities and financial frictions in the context of our model. The key to explaining the VAR evidence is the lack of flexibility in the labor market. This is crucial when there are sector-specific shocks.

\section{A. The Role of Labor Market Frictions}

In Figures 10 and 11 we plot how the effect of both shocks changes as we remove wage stickiness and indexation in both sectors (by setting

$\theta_{C, W}=\theta_{D, W}=\phi_{C, W}=\phi_{D, W}=0$ ), and the degree of labor market reallocation (by setting $\left.\iota_{L}=0\right)$. When we removed a rigidity we do so for both countries. The first result to note is that we do not find lack of comovement under a monetary policy shock. Even when both types of rigidities are eliminated, i.e. wages are allowed to be fully flexible and the work force can be reallocated instantaneously across sectors, non-durable output and durable output decrease after a monetary policy tightening. Sticky wages are key to explaining the fact that residential investment reacts more strongly than non-durable consumption to a monetary policy shock. When there are no labor market rigidities, real house prices experience a larger decline, and this tends to push demand for housing upwards because: a) housing becomes cheaper and b) it is expected to appreciate from a low level. By limiting the variability in real unit labor costs across sectors and hence the relative price differential, wage stickiness helps in lowering the response of residential investment and helps explain its higher sensitivity to interest rate changes. But it does not affect the comovement properties of the model. Given that the shock symmetrically affects both sectors, the introduction of labor market reallocation rigidities does not affect the results in an important way. 
On the other hand, since the housing preference shock is asymmetric by nature, the model needs the labor market reallocation rigidities to explain the VAR evidence. In Figure 11, we still calibrate the shock to deliver a 10 percent increase of residential investment under the benchmark calibration. We keep the same size of the shock as we change features of the model. When the workforce is allowed to be reallocated instantaneously after the shock, non-durable output decreases while durable output increases by a larger amount, making it impossible to explain comovement. Wage stickiness helps in increasing the persistent response of the endogenous variables to the shocks, but does not affect the comovement properties of the model under housing demand shocks. Therefore, the conclusion to this subsection is that costly labor reallocation helps explain the comovement between consumption and residential investment, while wage rigidities increase the response and persistence to shocks. Hence, both rigidities are needed.

\section{B. The Effects of Financial Frictions}

An important reason for concern for policy makers is the accelerator effect associated with fluctuations in housing prices. The nominal (and real) growth of the housing sector increases the amount of collateral available, allowing households to borrow more (or to save less in other instruments) and hence stimulates consumption. There is a well established literature that highlights the role of collateral as a key element in the amplification in the transmission mechanism of shocks through business investment (see Kiyotaki and Moore, 1997; and Bernanke, Gertler and Gilchrist, 1999). More recently, a new strand of the literature has focused on the role of residential investment in the transmission mechanism (see Aoki et al., 2004; Iacoviello, 2005; Iacoviello and Neri, 2010; and Monacelli, 2009). We therefore proceed with our analysis by studying how the impact of each shock changes when the fraction of credit-constrained agents increase, and/or their borrowing capacity changes.

To evaluate the importance of financial frictions we analyze how the impact of a monetary policy and housing preference shocks varies as the fraction of agents with limited borrowing capacity increases, and their pledging capacity changes. We extend the model of section 3 by assuming that a fraction $1-\lambda$ of agents face credit constraints. In particular, we assume that these agents, which are typically labelled as borrowers in the literature (see Monacelli, 2009), are more impatient than the regular agents, whose mass is $\lambda$, and that now we label as savers.

We denote all variables for borrowers with a superscript $B$. 


$$
E_{0}\left\{\sum_{t=0}^{\infty} \beta^{B, t}\left[\gamma \log \left(C_{t}^{B, j}-\varepsilon C_{t-1}^{B}\right)+(1-\gamma) \xi_{t}^{D} \log \left(D_{t}^{B, j}\right)-\frac{\left(L_{t}^{B, j}\right)^{1+\varphi}}{1+\varphi}\right]\right\}
$$

where all the indices of consumption and hours worked, and the law of motion of the housing stock are the same as for the case of savers. Note that borrowers are more impatient and discount the future at a lower rate: $\beta^{B}<\beta$. Their budget constraint in nominal terms is given by:

$$
P_{t}^{C} C_{t}^{B, j}+P_{t}^{D} I_{t}^{B, j}+\tilde{R}_{t-1} S_{t-1}^{B, j} \leq S_{t}^{B, j}+\frac{W_{t}^{C} L_{t}^{B, C, j}}{X_{t}^{C}}+\frac{W_{t}^{D} L_{t}^{B, D, j}}{X_{t}^{D}} .
$$

While borrowers can invest in housing, they do not own land as savers do. Also, borrowers do not have access to international capital markets, and hence they obtain credit from savers, who can trade in international bonds subject to an interest rate differential, just as in Section 3. Borrowers face a collateral constraint that is tied to the current value of durable goods (i. e. the housing stock they own):

$$
S_{t}^{B, j} \leq(1-\chi) D_{t}^{B, j} P_{t}^{D}
$$

One can interpret the fraction $\chi$ as a down-payment rate, and hence $(1-\chi)$ is the loan-to-value (LTV) ratio. When house prices increase, borrowers are able to borrow more in order to finance additional durable and non-durable consumption. ${ }^{14}$

We present the impact effect of monetary and housing demand shocks as a function of $\lambda$ and $\chi$ in Figures 12 and 13. All other parameter values are set to those in Table 1. We study an economy where $\lambda=0.5$ and that includes two levels of indebtedness of borrowers: a low level ( $\chi=0.5$, corresponding to an LTV ratio of 50 percent) and a high level ( $\chi=0.1$, which implies an LTV of 90 percent). We obtain similar results to those reported in the existing literature: the responses of both non-durables and durables consumption are larger when financial frictions are tighter. By financial frictions being tighter we mean that either there is a larger fraction of credit constrained agents (lower $\lambda$ ) in the economy and/or their borrowing capacity is more restricted (higher $\chi$ ).

After a monetary policy shock, the response of non-durable consumption does not appear to be sensitive to different levels of financial frictions. The effects on residential investment are more important, especially to different specifications of the LTV, $1-\chi$. The tighter the credit conditions (lower LTV), the larger is the response of durable output to a monetary contraction. The conclusions are similar when we analyze the housing preference shock. The response of consumption is

\footnotetext{
${ }^{14}$ In an appendix available upon request we detail the full set of log-linearized equations.
} 
barely affected by the presence of financial frictions, especially when agents can borrow against it, but the numerical differences are very small when comparing the response of non-durable consumption to residential investment. The tightness of credit conditions implicit in the LTV ratio affects the response of durable output, while the fraction of constrained agents in the economy does not appear to play a major role in amplifying the shock.

Overall, even if financial frictions seem to amplify the monetary and preference shocks, their quantitative effects are rather small when compared with a model with homogeneous agents and no credit constraints (but with labor market frictions). In Aspachs-Bracons and Rabanal (2010) we estimated that the fraction of financially constraints individuals in the Spanish economy was low and it did not improve model fit. In the same spirit, Darracq-Parriès and Notarpietro (2009) have difficulty identifying the fraction of credit-constrained individuals in a DSGE model of the euro area, and show that this extension does not improve model fit.

This does not mean credit constraints are not present in the Spanish or EMU data. But they need to be modelled in a different way than has been included in the literature since Iacoviello (2005). One avenue to study would be to allow agents to borrow against their labor income, in addition to housing collateral.

\section{The Effects of Belonging to the EMU}

The tools available to Spanish policymakers to react to shocks were reduced substantially when Spain joined the EMU. To analyze the consequences of having abandoned monetary policy independence, we extend the model of Section 3 by assuming that both countries can run their own monetary policy with different national currencies as units of account. ${ }^{15}$ We therefore introduce Taylor rules for both countries (Spain, and an EMU without Spain) and an uncovered interest rate parity condition, and we assume producer currency pricing for imports and exports of non-durable goods, as in Lubik and Schorfheide (2006). The goal is to study the reaction of a small open economy in a two country model when faced with housing demand shocks. It is important to note that this paper studies the 1996-2007 period, and the exercise only focuses on the possible costs of not being able to address demand-specific shocks in one sector or country using monetary policy. Our model does not evaluate other important costs of not belonging to the EMU such as those associated with exchange rate volatility (e.g. higher domestic interest rates and lower international trade) which could affect growth.

\footnotetext{
${ }^{15}$ Of course, the model abstracts from other potential benefits of joining a monetary union, like the disappearance of exchange rate risk and the lowering of risk premia.
} 
In log linear terms, the uncovered interest rate parity reads as follows:

$$
r_{t}-r_{t}^{*}=E_{t} n e r_{t+1}-n e r_{t}-\kappa b_{t}
$$

where $n e r_{t}$ is the (log deviation from the steady state) of the nominal exchange rate, defined as units of home country currency per unit of foreign country currency. This equation links the interest rate differential to the expected depreciation of the currency, and also includes the endogenous risk premium depending on the net foreign asset position as percent of GDP of the economy $\left(b_{t}\right)$.

In this case, the domestic interest rate becomes $r_{t}$, while the foreign interest rate is $r_{t}^{*}$, and both follow Taylor rules targeting domestic CPI inflation:

$$
\begin{aligned}
r_{t} & =\gamma_{R} r_{t-1}+\left(1-\gamma_{R}\right) \gamma_{\pi} \Delta p_{t}^{C}+\left(1-\gamma_{R}\right) \gamma_{D} \Delta p_{t}^{D} \\
r_{t}^{*} & =\gamma_{R}^{*} r_{t-1}^{*}+\left(1-\gamma_{R}^{*}\right) \gamma_{\pi} \Delta p_{t}^{C^{*}}
\end{aligned}
$$

Note that we assume that the coefficients of the Taylor rule $\left(\gamma_{R}\right.$ and $\left.\gamma_{\pi}\right)$ are the same across countries. In addition, we consider that the home country can either

run a strict inflation targeting regime $\left(\gamma_{D}=0\right)$, or react to deviations in the durable price inflation rate, $\gamma_{D}>0$.

Finally, since we have assumed that there is producer currency pricing and that the law of one price holds, non-durables inflation in both countries is given by:

$$
\begin{aligned}
\Delta p_{t}^{C} & =\tau \Delta p_{H, t}+(1-\tau)\left(\Delta p_{F, t}+\Delta s_{t}\right) \\
\Delta p_{t}^{C^{*}} & =\left(1-\tau^{*}\right)\left(\Delta p_{H, t}-\Delta s_{t}\right)+\tau^{*} \Delta p_{F, t}
\end{aligned}
$$

such that movements in the nominal exchange rate affect directly the price of imports and exports.

\section{A. Impulse Response from The Model}

In Figure 14 we compare the impulse response functions of a housing demand shock under a fixed exchange rate, a pure floating inflation targeting regime and a pure floating regime with housing inflation targeting. We use the same calibrations discussed in Table 1. When we refer to the "No EMU" we set the parameter $\gamma_{D}=0$, while in the "No EMU-HP targeting" we set the parameter $\gamma_{D}=0.5$. We have also studied the case in which the Spain Taylor rule targets the nominal exchange rate, which results in an intermediate case between joining the EMU and running strict inflation targeting.

Under a housing demand shock of the same size, the response of output is almost 
the same when Spain belongs to the EMU or not. The small impact of this shock into the euro area economy produces no reaction from the monetary authority, and the Spanish economy experiences high growth rates in the durable sector, while the non-durable sector barely reacts, and CPI-inflation does not change either. This explains why the response of the main variables is almost the same because the difference in the CPI inflation paths does not justify a stronger reaction from the monetary authority outside the EMU.

Finally, we analyze the implications of having a monetary authority that not only reacts to CPI inflation, but also to deviations in housing prices. The rationale for this case is that we assume that the hypothetical monetary policy in Spain would try to "lean against the wind" when faced with increasing house prices. After a housing demand shock, inflation in the durable sector increases. Therefore, the response of the monetary authority in this case consists of increasing interest rates, which reduces non-durable consumption and residential investment, and CPI inflation. Nominal house prices decline but real house prices increase. The collapse in non-durable consumption comes from two channels. The first channel is higher interest rates, and the second is the nominal exchange rate appreciation that comes with higher interest rates.

Therefore, the monetary policy trade-off is the following: to offset the effects of a housing demand shock, a recession in the non-durable sector of the economy is necessary, a politically unacceptable consequence to many central banks. To the extent that these reduced form demand shocks are capturing other developments in the credit or housing markets (for instance, lax credit practices or tax breaks for home ownership), using another tool directed at those imperfections would be better than having monetary policy address these distortions directly.

\section{B. Counterfactual Simulation of The Model}

After having shown the different impulse responses of the economy to housing demand shocks depending on the monetary policy regime, this subsection performs a somewhat related exercise. The time series of housing demand shocks is obtained from the VAR using the Cholesky decomposition, and the shocks are fed into the DSGE model. Actually, the shocks are the same than the ones used in the historical decomposition in Section 2.4. Then, we analyze the role of the different policy rules, including the counterfactual where Spain was outside the EMU. Figure 15 shows the results. The red bar shows the behavior of the model with a currency union with the rest of the EMU. Housing demand shocks mostly have an effect on residential investment and house prices, and they also spill over to consumption and real GDP, although the effect is quantitatively much smaller, as was shown in the VAR section. 
The green bar shows what happens under the counterfactual where Spain is outside the euro and the central bank reacts to house prices. The monetary authorities cannot do much to reduce the volatility of the housing variables (prices and investment), even when they "lean against the wind." On the other hand, the volatility of output and consumption increases when the central bank reacts to house price fluctuations under house price demand shocks. In downturns, reacting to house prices is desirable as it stimulates the economy. But in the upturns, it leads to the opposite effect, and can put the economy into a recession. So overall, it is not desirable to react to house prices because doing so increases volatility on other macroeconomic variables.

\section{Concluding Remarks}

In this paper we have studied the recent evidence on interest rates, housing prices and residential investment in Spain. We have presented some evidence based on a VAR model, and have rationalized our findings with a two-country, two-sector model with housing demand and monetary shocks. One important caveat to the VAR evidence is that the sample period for the VAR only includes a decade of data during a period of transition, and hence the empirical analysis may be subject to nontrivial small-sample bias - an issue recently emphasized by Chari, Kehoe, and McGrattan (2008). Perhaps one direction for further research would be to use artificial data drawn from stochastic simulations of the DSGE model in order to obtain a rough gauge of the small-sample properties of the empirical analysis.

We have also examined the key features of the model in order to help explain the results. Of all the mechanisms suggested in the literature, labor market rigidities are necessary to obtain the right comovement between the two sectors of the economy. The introduction of financial frictions helps in increasing the response of non-durable goods consumption to both shocks, but this increase can also be achieved under other modeling assumptions. The model is linearized around a steady state, assuming no imbalances in trade or the current account. While this approach simplifies the analysis considerably, it does seem to be a important departure from reality. Future research regarding the implications of linearizing the model around a qualitatively different steady state.should be considered.

We have studied the cost of losing monetary autonomy (i.e. through currency union membership). We conclude that the behavior of the Spanish economy under its own monetary policy or under euro membership does not change the outcome to a housing demand shock due to the following reason: even if the shock has important effects on residential investment and house prices, Spanish CPI inflation does not change, and hence an inflation targeting monetary authority remains passive in 
either case. However, if the Spanish monetary authority reacts to housing price changes, the response of the main variables differs substantially, with high costs in the non-durable sector: non-durable output suffers an important and persistent contraction. Hence, it is not clear at all that if Spain had not belonged to the EMU the boom-and-bust cycle in housing prices between 1996-2007 could have been avoided by using monetary policy.

The case of other advanced economies provides additional evidence to support this argument. Fatás et al. (2009) and Dokko et al. (2009) study the relationship between the stance of monetary policy (proxied by Taylor rule residuals) and real house price increases during 2002-2006. Both studies find that the cross-country relationship between the two variables is statistically weak. Both studies single out the case of Spain, where monetary policy was about 300 basis points on average below the prescriptions of a standard Taylor rule, and house prices appreciated about 80 percent. But both studies also mention the cases of the United Kingdom, New Zealand and Australia where monetary policy was not loose and yet the housing price boom was sizable. ${ }^{16}$ Finally, Dokko et al. (2009) provide simulations based on the FRBUS model and conclude, as we have shown in this paper, that monetary policy tightening would likely only have marginal effects in containing a house price bubble and might well be detrimental to other sectors of the economy.

\footnotetext{
${ }^{16}$ In this context, it might be interesting to note the position of the newly elected government in the U.K. who is inclined to incorporate housing prices in a comprehensive measure of consumer prices. In his letter of May 18, 2010 to the Governor of the Bank of England, the Chancellor of the Exchequer George Osborne mentioned that "As we have discussed, over the longer term I would welcome your views on how we might accelerate the process of including housing costs in the CPI inflation target." The letter is available at http://www.hm-treasury.gov.uk/ukecon_mon_index.htm
} 


\section{References}

Aoki, K., Proudman, J. and G. Vlieghe, 2004, "House Prices, Consumption and Monetary Policy: A Financial Accelerator Approach," Journal of Financial Intermediation, 13(4), pp. 414-35.

Aspachs-Bracons, O. and Rabanal, P., 2010, "The Drivers of Housing Cycles in Spain," Series: Journal of the Spanish Economic Association, Vol. 1-2, (March), pp. 101-30.

Benigno, P., 2004, "Optimal Monetary Policy in a Currency Area," Journal of International Economics, Volume 63, Issue 2, Pages 293-320.

Bernanke, B., Blinder, A., 1992, "The Federal Funds Rate and the Channels of Monetary Transmission," American Economic Review, Vol. 82(4), pp. 901-21.

Bernanke, B., Gertler, M., and Gilchrist, S., 1999, "The Financial Accelerator in a Quantitative Business Cycle Framework," in J. B. Taylor \& M. Woodford (eds.), Handbook of Macroeconomics, Volume 1, Chapter 21, pp. 1341-93.

Bils, M. and Klenow, P., 2004, "Some Evidence On the Importance of Sticky Prices," Journal of Political Economy, Vol. 112(5), pp. 947-85.

Bover, O., 2005, "Wealth Effects on Consumption: Microeconometric Estimates from a New Survey of Household Finances," Banco de España, Working Paper 0522 .

Calvo, G., 1983, "Staggered Prices in A Utility Maximizing Framework," Journal of Monetary Economics, Vol. 12, pp. 383-98.

Cardarelli, R., Monacelli, T., Rebucci, A., and Sala, L., 2009, "Housing Finance, Housing Shocks and the Business Cycle: Evidence from OECD Countries," mimeo, IMF and InterAmerican Development Bank.

Carlstrom, C. T., Fuerst, T. 2007, "Co-Movement in Sticky Price Models with Durable Goods," Working Paper 0614, Federal Reserve Bank of Cleveland.

Chari, V.V., Kehoe, P., and McGrattan, E., 2008, "Are Structural VARs with Long-Run Restrictions Useful in Developing Business Cycle Theory?," Journal of Monetary Economics, Vol. 55(8), pp. 1337-52.

Christiano, L., Eichenbaum, M., and Evans, C., 1999, "Monetary Policy Shocks: What Have We Learned and To What End?," in J. B. Taylor \& M. Woodford (eds.), Handbook of Macroeconomics, Volume 1, Chapter 2, pp. 65-148. , 2005, "Nominal Rigidities and The Dynamic Effects of A Shock to 
Monetary Policy," Journal of Political Economy, Vol. 113, pp. 1-45.

Darracq-Pariès, M., and Notarpietro, A., 2009, "Monetary Policy and Housing Prices in An Estimated DSGE Model for the US and the Euro Area," Working Paper Series 972, European Central Bank.

Di Ceccio, R., 2009, "Sticky Wages and Sectoral Labor Comovement," Journal of Economic Dynamics and Control, Vol. 33, pp. 538-553.

Dokko, J., Doyle, B., Kiley, M., Kim, J., Sherlund, S., Sim, J., Van den Heuvel, S., 2009, Monetary, "Policy and the Housing Bubble," Finance and Economics Discussion Series Working Paper 2009-49, Board of Governors of the Federal Reserve System.

Erceg, C., and Levin, A. 2006, "Optimal Monetary Policy with Durable Consumption Goods," Journal of Monetary Economics, Vol. 53 (7), pp. 1341-59.

Fabiani, S., Druant, M., Hernando, I., Kwapil, C., Landau, B., Loupias, C., Martins, F., Mathä, T., Sabbatini, R., Stahl, H., and Stokman, A., 2006, "What Firms' Surveys Tell Us About Price-Setting Behavior in the Euro Area," International Journal of Central Banking, Vol. 2, Number 3, pp. 3-47.

Fatás, A., Kannan, P., Rabanal, P., and Scott, A., 2009, "Lessons For Monetary Policy From Asset Price Fluctuations," Chapter 3 of October 2009 World Economic Outlook. International Monetary Fund, Washington, DC.

Iacoviello M., and Neri, S., 2010, "The Role of Housing Collateral in An Estimated Two-Sector Model of the U.S. Economy," American Economic Journal: Macroeconomics, Vol. 2, No. 2, April, pp. 125-64.

Iacoviello, M., 2005, "House Prices, Borrowing Constraints and Monetary Policy in the Business Cycle," American Economic Review, Vol. 95 (3), pp. 739-64.

Kiyotaki, N., and Moore, J., 1997, "Credit Cycles," Journal of Political Economy, Vol. 105(2), pp. 211-48.

Lubik T. and F. Schorfheide, 2006, "A Bayesian Look at New Open Economy Macroeconomics," In: Gertler, M., Rogoff, K. (Eds.), NBER Macroeconomics Annual, Vol. 20, The MIT Press, Cambridge, pp. 313-80.

Mishkin, F., 2007, "Housing and The Monetary Transmission Mechanism," NBER Working Paper 13518.

Monacelli T., 2009, "New Keynesian Models, Durable Goods, and Collateral Constraints," Journal of Monetary Economics, Volume 56:2, pp. 242-54. 
Rabanal, P., 2009, "Inflation Differentials Between Spain and the EMU: a DSGE Perspective," Journal of Money, Credit and Banking, Vol. 41, pp 1141-66.

Schmitt-Grohe, S., and Uribe, M., 2003, "Closing Small Open Economy Models," Journal of International Economics, Vol. 61, pp. 163-185.

Smets, F. and R. Wouters, 2003, "An Estimated Stochastic Dynamic General Equilibrium Model for the Euro Area," Journal of the European Economic Association, Vol. 1, pp. 1123-1175.

Uhlig, H., 2005, "What Are The Effects of Monetary Policy on Output? Results from An Agnostic Identification Procedure," Journal of Monetary Economics, Vol. 52, pp. 381-419. 


\section{A Appendix: Linear Approximation}

Here we present the loglinear conditions. Also, we define the relative price of durables in terms of non-durables as $Q_{t}=\frac{P_{t}^{D}}{P_{t}^{C}}$, and the terms of trade as $T_{t}=\frac{P_{F, t}}{P_{H, t}}$. Also, $\omega_{t}^{i}$ denotes deviations from the real wage from steady-state values, defined as nominal wage $\left(W_{t}^{i}\right)$ divided by the CPI $\left(P_{t}^{C}\right)$, for $i=C, D$. From the optimal decisions by households we get the following:

$$
q_{t}-\frac{c_{t}-\varepsilon c_{t-1}}{1-\varepsilon}+\psi\left(i_{t}-i_{t-1}\right)=\mu_{t}+\beta \psi\left(E_{t} i_{t+1}-i_{t}\right)
$$

where $\psi=S^{\prime \prime}($.$) .$

$$
\begin{gathered}
{[1-\beta(1-\delta)]\left(\xi_{t}^{D}-d_{t}\right)=\mu_{t}-\beta(1-\delta) E_{t} \mu_{t+1}} \\
q_{t}=q_{t-1}+\Delta p_{t}^{D}-\Delta p_{t}^{C} \\
\varepsilon \Delta c_{t}=E_{t} \Delta c_{t+1}-(1-\varepsilon)\left(\tilde{r}_{t}-E_{t} \Delta p_{t+1}^{C}\right)
\end{gathered}
$$

Under Calvo wage setting and with partial indexation to past non-durable (CPI) inflation (with coefficients $\varphi_{C, W}$ and $\varphi_{D, W}$ ), the wage-setting equations can be loglinearized into to the following wage Philips curves:

$$
\begin{gathered}
\omega_{t}^{C}-\omega_{t-1}^{C}+\Delta p_{t}^{C}-\varphi_{C, W} \Delta p_{t-1}^{C}=\beta E_{t}\left(\omega_{t+1}^{C}-\omega_{t}^{C}+\Delta p_{t+1}^{C}-\varphi_{C, W} \Delta p_{t}^{C}\right) \\
+\kappa^{C, W}\left[\frac{c_{t}-\varepsilon c_{t-1}}{1-\varepsilon}+[(\varphi-\iota) \alpha+\iota] l_{t}^{C}+(\varphi-\iota)(1-\alpha) l_{t}^{D}-\omega_{t}^{C}\right]
\end{gathered}
$$

where $\kappa^{C, W}=\frac{\left(1-\theta_{C, W}\right)\left(1-\beta \theta_{C, W}\right)}{\theta_{C, W}}$, and

$$
\begin{gathered}
\omega_{t}^{D}-\omega_{t-1}^{D}+\Delta p_{t}^{C}-\varphi_{D, W} \Delta p_{t-1}^{C}=\beta E_{t}\left(\omega_{t+1}^{D}-\omega_{t}^{D}+\Delta p_{t+1}^{C}-\varphi_{D, W} \Delta p_{t}^{C}\right) \\
+\kappa^{D, W}\left[\frac{c_{t}-\varepsilon c_{t-1}}{1-\varepsilon}+[(\varphi-\iota)(1-\alpha)+\iota] l_{t}^{D}+(\varphi-\iota) \alpha l_{t}^{C}-\omega_{t}^{D}\right]
\end{gathered}
$$

where $\kappa^{D, W}=\frac{\left(1-\theta_{D, W}\right)\left(1-\beta \theta_{D, W}\right)}{\theta_{D, W}}$. 
The relationship between the domestic and the EMU-wide interest rates is as follows:

$$
\tilde{r}_{t}=r_{t}-\kappa \hat{b}_{t}
$$

where $\hat{b}_{t}=\left(B_{t} / Y_{t} P_{t}\right)$ denotes the deviation of foreign assets as percent of GDP from its steady-state value of zero. The evolution of net foreign assets is:

$$
\hat{b}_{t}=\frac{1}{\beta} \hat{b}_{t-1}+\frac{(1-n)\left(1-\tau^{*}\right)}{n}\left(c_{H, t}^{*}-t_{t}\right)-(1-\tau) c_{F, t}
$$

The evolution of domestic and imported non-durable consumption is

$$
\begin{gathered}
c_{H, t}=(1-\tau) t_{t}+c_{t} \\
c_{F, t}=-\tau t_{t}+c_{t}
\end{gathered}
$$

Here we list the evolution of the foreign country variables for households:

$$
\begin{aligned}
& q_{t}^{*}-\frac{c_{t}^{*}-\varepsilon c_{t-1}^{*}}{1-\varepsilon}+\psi\left(i_{t}^{*}-i_{t-1}^{*}\right)=\mu_{t}^{*}+\beta \psi\left(E_{t} i_{t+1}^{*}-i_{t}^{*}\right) \\
& {[1-\beta(1-\delta)]\left(\xi_{t}^{D^{*}}-d_{t}^{*}\right)=\mu_{t}^{*}-\beta(1-\delta) E_{t} \mu_{t+1}^{*}} \\
& q_{t}^{*}=q_{t-1}^{*}+\Delta p_{t}^{D^{*}}-\Delta p_{t}^{C^{*}} \\
& \varepsilon \Delta c_{t}^{*}=E_{t} \Delta c_{t+1}^{*}-(1-\varepsilon)\left(r_{t}-E_{t} \Delta p_{t+1}^{C^{*}}\right) \\
& \omega_{t}^{C^{*}}-\omega_{t-1}^{C^{*}}+\Delta p_{t}^{C^{*}}-\varphi_{W C} \Delta p_{t-1}^{C^{*}}=\beta E_{t}\left(\omega_{t+1}^{C^{*}}-\omega_{t}^{C^{*}}+\Delta p_{t+1}^{C^{*}}-\varphi_{C, W} \Delta p_{t}^{C^{*}}\right)+ \\
& \kappa^{C, W}\left[\frac{c_{t}^{*}-\varepsilon c_{t-1}^{*}}{1-\varepsilon}+\left[\left(\varphi^{*}-\iota^{*}\right) \alpha^{*}+\iota^{*}\right] l_{t}^{C^{*}}+\left(\varphi^{*}-\iota^{*}\right)\left(1-\alpha^{*}\right) l_{t}^{D^{*}}-\omega_{t}^{C^{*}}\right] \\
& \omega_{t}^{D^{*}}-\omega_{t-1}^{D^{*}}+\Delta p_{t}^{C^{*}}-\varphi_{D, W} \Delta p_{t-1}^{C^{*}}=\beta E_{t}\left(\omega_{t+1}^{D^{*}}-\omega_{t}^{D^{*}}+\Delta p_{t+1}^{C^{*}}-\varphi_{D, W} \Delta p_{t}^{C^{*}}\right)+
\end{aligned}
$$




$$
\kappa^{D, W}\left[\frac{c_{t}^{*}-\varepsilon c_{t-1}^{*}}{1-\varepsilon}+\left[\left(\varphi^{*}-\iota^{*}\right)\left(1-\alpha^{*}\right)+\iota^{*}\right] l_{t}^{D^{*}}+\left(\varphi^{*}-\iota^{*}\right) \alpha^{*} l_{t}^{C^{*}}-\omega_{t}^{D^{*}}\right]
$$

where $\kappa^{C, W}$ and $\kappa^{D, W}$ are the same as in the home country. The demand for foreign and domestic goods is:

$$
\begin{gathered}
c_{H, t}^{*}=\tau^{*} t_{t}+c_{t}^{*} \\
c_{F, t}^{*}=-\left(1-\tau^{*}\right) t_{t}+c_{t}^{*}
\end{gathered}
$$

where we have used the definition of the terms of trade, the fact that $t_{t}=-t_{t}^{*}$, and the evolution of the terms of trade is given by:

$$
t_{t}=t_{t-1}+\Delta p_{t}^{F}-\Delta p_{t}^{H}
$$

The deflators of the final goods are

$$
\begin{gathered}
\Delta p_{t}=\gamma \Delta p_{t}^{C}+(1-\gamma) \Delta p_{t}^{D} \\
\Delta p_{t}^{*}=\gamma^{*} \Delta p_{t}^{C^{*}}+\left(1-\gamma^{*}\right) \Delta p_{t}^{D^{*}}
\end{gathered}
$$

where CPI inflation is given by

$$
\begin{aligned}
\Delta p_{t}^{C} & =\tau \Delta p_{H, t}+(1-\tau) \Delta p_{F, t} \\
\Delta p_{t}^{C^{*}} & =\left(1-\tau^{*}\right) \Delta p_{H, t}+\tau^{*} \Delta p_{F, t}
\end{aligned}
$$

The production functions are given by:

$$
\begin{gathered}
y_{t}^{C}=l_{t}^{C} \\
y_{t}^{D}=\alpha^{D} l_{t}^{D} \\
y_{t}^{C^{*}}=l_{t}^{C^{*}} \\
y_{t}^{D^{*}}=\alpha^{D} l_{t}^{D^{*}}
\end{gathered}
$$

And the pricing equations are given by

$$
\Delta p_{t}^{H}-\varphi_{C} \Delta p_{t-1}^{H}=\beta E_{t}\left(\Delta p_{t+1}^{H}-\varphi_{C} \Delta p_{t}^{H}\right)+\kappa^{C}\left[\omega_{t}^{C}+(1-\tau) t_{t}\right]
$$


where $\kappa^{C}=\frac{\left(1-\theta_{C}\right)\left(1-\beta \theta_{C}\right)}{\theta_{C}}$.

$$
\Delta p_{t}^{D}-\varphi_{D} \Delta p_{t-1}^{D}=\beta E_{t}\left(\Delta p_{t+1}^{D}-\varphi_{D} \Delta p_{t}^{D}\right)+\kappa^{D}\left[\omega_{t}^{D}+\left(1-\alpha^{D}\right) l_{t}^{D}-q_{t}\right]
$$

where $\kappa^{D}=\frac{\left(1-\theta_{D}\right)\left(1-\beta \theta_{D}\right)}{\theta_{D}}$.

For the foreign country, after assuming symmetric Calvo parameters, we get that:

$$
\begin{gathered}
\Delta p_{t}^{F}-\varphi_{C} \Delta p_{t-1}^{F}=\beta E_{t}\left(\Delta p_{t+1}^{F}-\varphi_{C} \Delta p_{t}^{F}\right)+\kappa^{C}\left[\omega_{t}^{C^{*}}-\left(1-\tau^{*}\right) t_{t}\right] \\
\Delta p_{t}^{D^{*}}-\varphi_{D} \Delta p_{t-1}^{D^{*}}=\beta E_{t}\left(\Delta p_{t+1}^{D^{*}}-\varphi_{D} \Delta p_{t}^{D^{*}}\right)+\kappa^{D}\left[\omega_{t}^{D^{*}}+\left(1-\alpha^{D}\right) l_{t}^{D^{*}}-q_{t}^{*}\right]
\end{gathered}
$$

The market clearing conditions for the goods sectors read as follows:

$$
\begin{gathered}
y_{t}^{C}=\tau c_{H, t}+\frac{(1-n)\left(1-\tau^{*}\right)}{n} c_{H, t}^{*} \\
y_{t}^{C^{*}}=\tau^{*} c_{F, t}^{*}+\frac{n(1-\tau)}{1-n} c_{F, t} \\
d_{t}=(1-\delta) d_{t-1}+\delta y_{t}^{D} \\
d_{t}^{*}=(1-\delta) d_{t-1}^{*}+\delta^{*} y_{t}^{D^{*}} \\
y_{t}^{D}=i_{t} \\
y_{t}^{D^{*}}=i_{t}^{*}
\end{gathered}
$$

while for the labor market it is:

$$
\begin{gathered}
l_{t}^{t o t}=\alpha l_{t}^{C}+(1-\alpha) l_{t}^{D} \\
l_{t}^{t o t, *}=\alpha^{*} l_{t}^{C^{*}}+\left(1-\alpha^{*}\right) l_{t}^{D^{*}}
\end{gathered}
$$

To close the model, we specify a monetary policy Taylor rule conducted by the ECB:

$$
r_{t}=\gamma_{R} r_{t-1}+\left(1-\gamma_{R}\right)\left(\Delta p_{t}^{E M U}\right)+\varepsilon_{t}^{m}
$$

where the euro area CPI is given by

$$
\Delta p_{t}^{E M U}=n \Delta p_{t}^{C}+(1-n) \Delta p_{t}^{C^{*}}
$$




\section{B Tables and Figures}

Table 1: Calibrated Parameters of the Model

\begin{tabular}{lll}
\hline \hline$n$ & Size of Spain inside the EMU & 0.1 \\
$\alpha$ & Share of the non-durable sector in the GDP & 0.9 \\
$1-\tau$ & Fraction of EMU imports consumed in Spain & 0.15 \\
$1-\tau^{*}$ & Fraction of Spain imports goods consumed in the EMU & 0.015 \\
$\kappa$ & Debt elasticity of the domestic interest rate & 0.02 \\
$\sigma_{C}, \sigma_{D}$ & Elasticity of substitution between intermediate goods & 10 \\
$\beta$ & Discount factor & 0.99 \\
$\delta$ & Depreciation rate of housing stock & 0.025 \\
$\varepsilon$ & Habit formation & 0.4 \\
$\eta$ & Labor supply elasticity & 0.9 \\
$\iota_{C}$ & Elasticity of subs. between goods & 4.4 \\
$\iota_{L}$ & Costly labor reallocation & 1.3 \\
$\gamma$ & Share of non-durable consumption in the utility function & 0.82 \\
$\psi$ & Investment adjustment costs & 0.3 \\
$\theta_{C}$ & Calvo lottery for the non-durable sector, prices & 0.87 \\
$\theta_{D}$ & Calvo lottery for the durable sector, prices & 0.34 \\
$\theta_{C, W}$ & Calvo lottery for the non-durable sector, wages & 0.75 \\
$\theta_{D, W}$ & Calvo lottery for the durable sector, wages & 0.75 \\
$\phi_{C}$ & Price indexation, non-durables & 0.5 \\
$\phi_{D}$ & Price indexation, durables & 0.7 \\
$\phi_{C, W}$ & Wage indexation, non-durables & 1 \\
$\phi_{D, W}$ & Wage indexation, durables & 1 \\
$\gamma^{\pi}$ & Inflation parameter of the Taylor rule & 1.25 \\
$\gamma^{R}$ & Interest rate smoothing parameter of the Taylor rule & 0.77 \\
\hline \hline
\end{tabular}


Table 2: Variance Decomposition VAR

\begin{tabular}{cccccccccc}
\hline \hline & \multicolumn{4}{c}{ Consumption } & \multicolumn{3}{c}{ Investment } & \multicolumn{3}{c}{ Real GDP } \\
\hline Horizon & MP & HD & Other & MP & HD & Other & MP & HD & Other \\
\hline 1 & 0.0 & 0.0 & 100.0 & 0.0 & 0.0 & 100.0 & 0.0 & 0.0 & 100.0 \\
2 & 0.2 & 4.4 & 95.4 & 1.2 & 18.1 & 80.6 & 0.0 & 0.2 & 99.8 \\
3 & 0.2 & 7.5 & 92.3 & 2.9 & 25.8 & 71.3 & 0.2 & 2.0 & 97.9 \\
4 & 1.3 & 10.4 & 88.3 & 5.0 & 28.3 & 66.6 & 1.1 & 4.1 & 94.9 \\
5 & 4.1 & 13.9 & 82.0 & 7.3 & 29.3 & 63.3 & 3.1 & 6.7 & 90.2 \\
10 & 19.2 & 26.0 & 54.8 & 13.1 & 28.5 & 58.5 & 19.1 & 23.6 & 57.3 \\
15 & 17.9 & 25.4 & 56.6 & 12.8 & 26.5 & 60.7 & 19.3 & 25.9 & 54.8 \\
25 & 15.0 & 24 & 61.0 & 12.1 & 25.5 & 62.4 & 15.6 & 24.3 & 60.1 \\
\hline \multicolumn{1}{c}{ Interest Rate } & House Prices & & & \\
\hline 1 & 96.4 & 0.0 & 3.6 & 0.1 & 84.9 & 15.1 & & & \\
2 & 79.6 & 0.8 & 19.5 & 2.2 & 71.8 & 26.0 & & & \\
3 & 66.7 & 4.7 & 28.6 & 6.0 & 54.6 & 39.4 & & & \\
4 & 55.5 & 8.0 & 36.5 & 9.6 & 42.3 & 48.2 & & & \\
5 & 46.8 & 10.1 & 43.0 & 12.0 & 35.0 & 53.0 & & & \\
10 & 29.4 & 12.9 & 57.6 & 14.0 & 24.1 & 61.9 & & & \\
15 & 27.7 & 12.9 & 59.4 & 12.9 & 22.6 & 64.6 & & & \\
25 & 27.4 & 13.1 & 59.5 & 12.3 & 22.4 & 65.3 & & & \\
\hline \hline
\end{tabular}




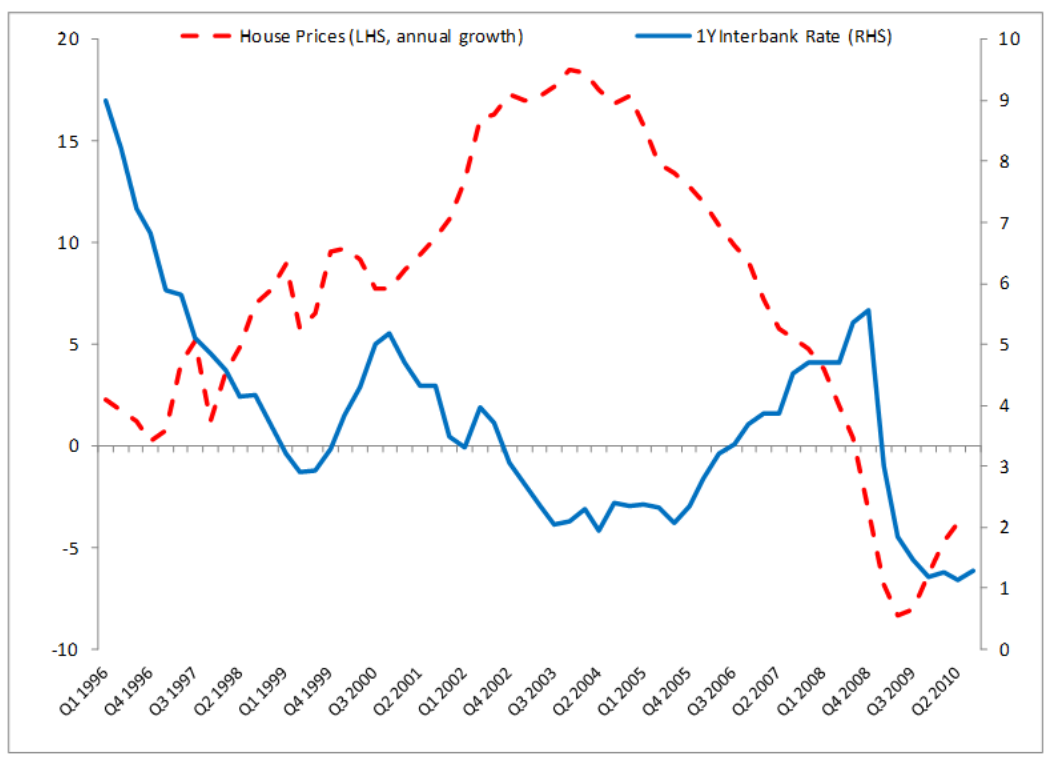

Figure 1: Nominal house prices and interest rates.

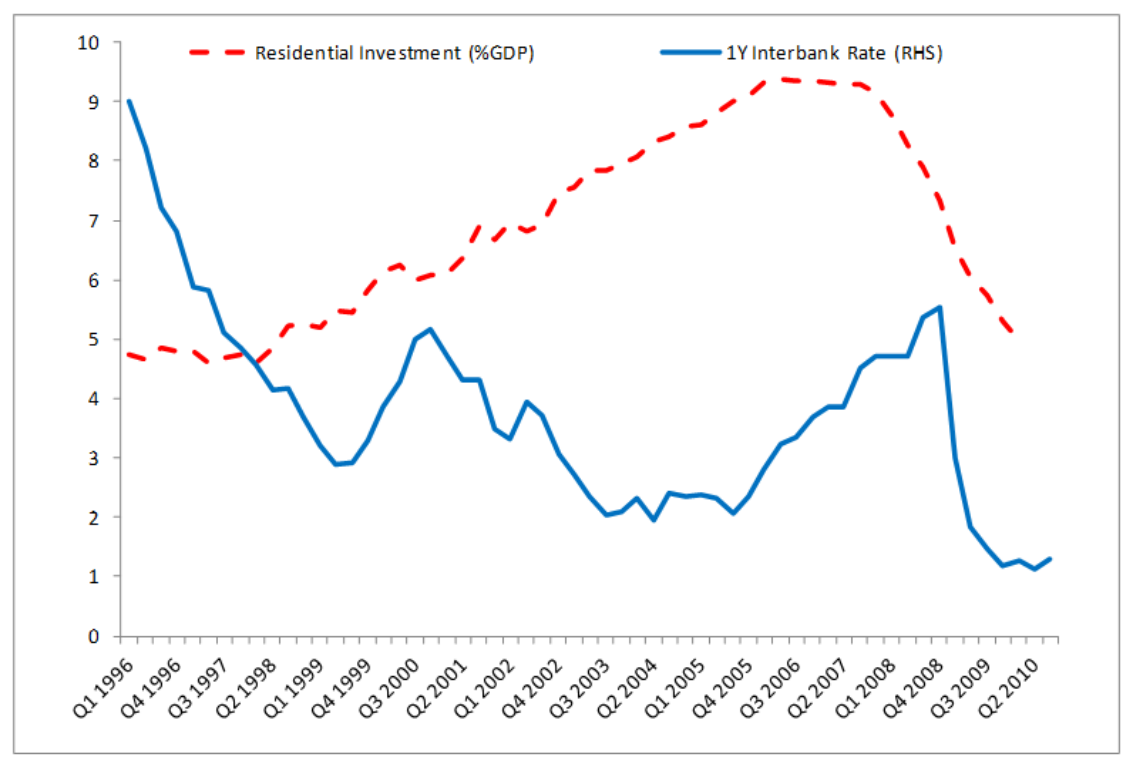

Figure 2: Residential investment and interest rates. 


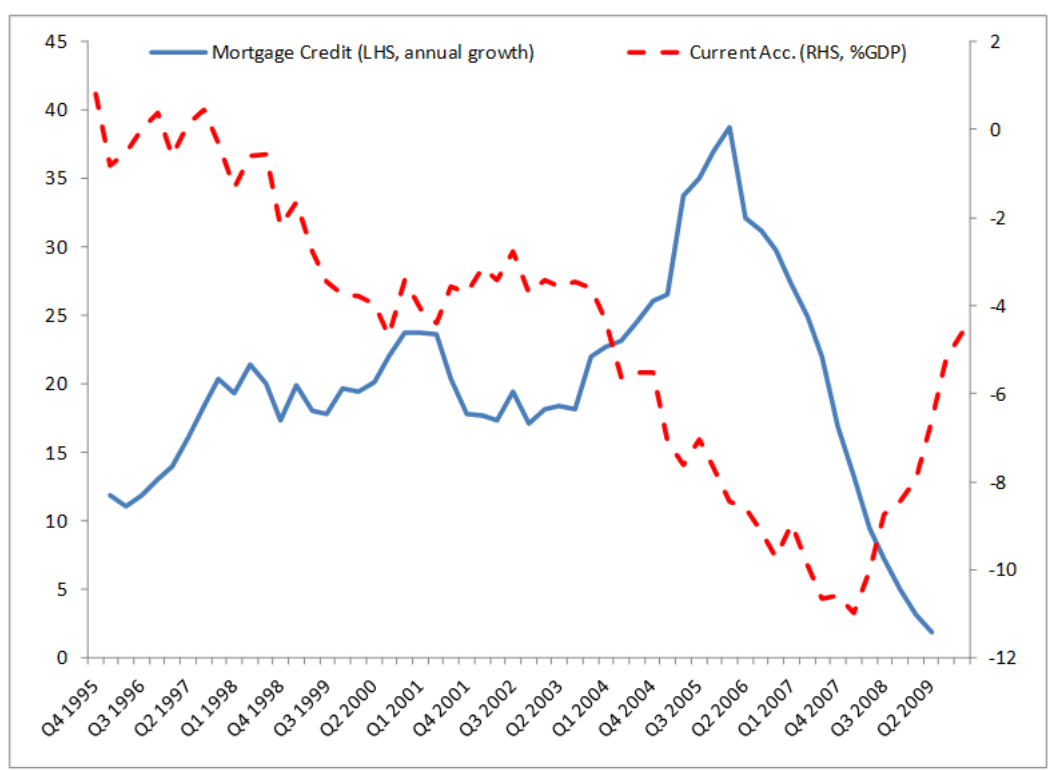

Figure 3: Mortgage credit and the current account.

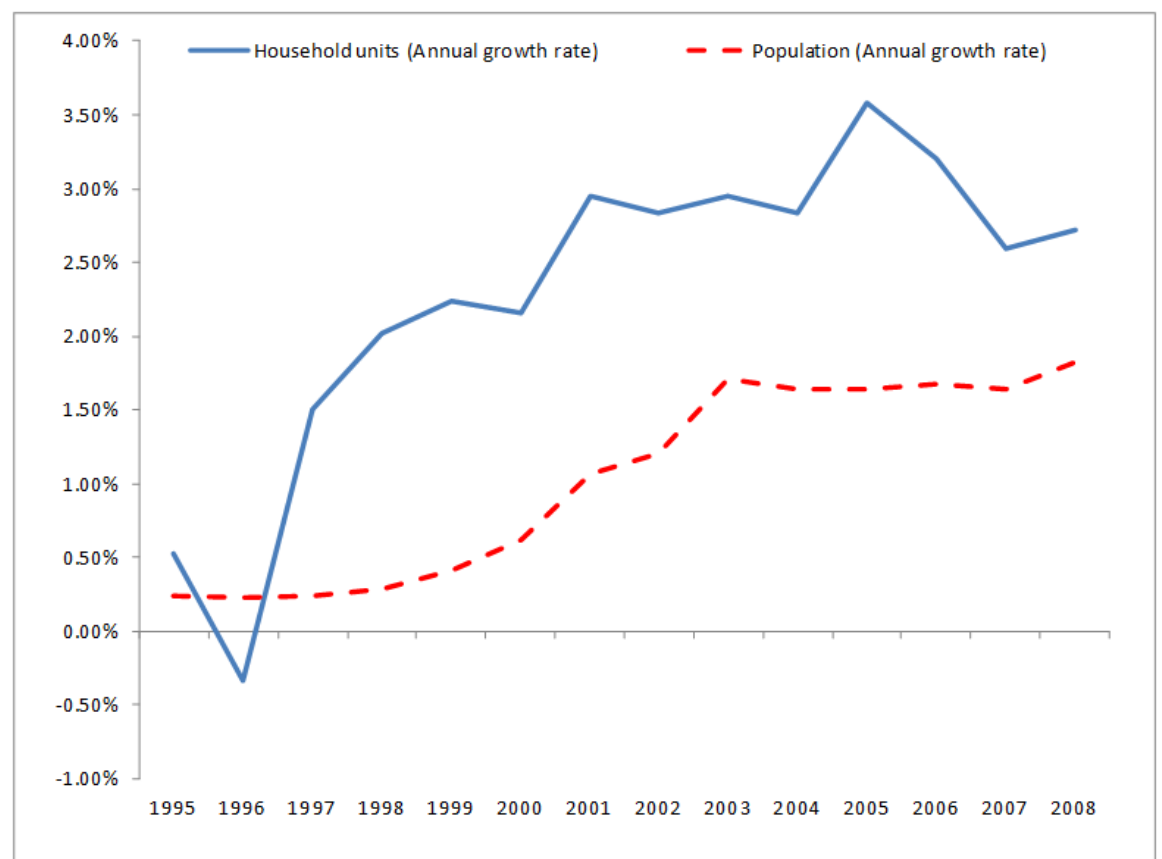

Figure 4: Demographic patterns 


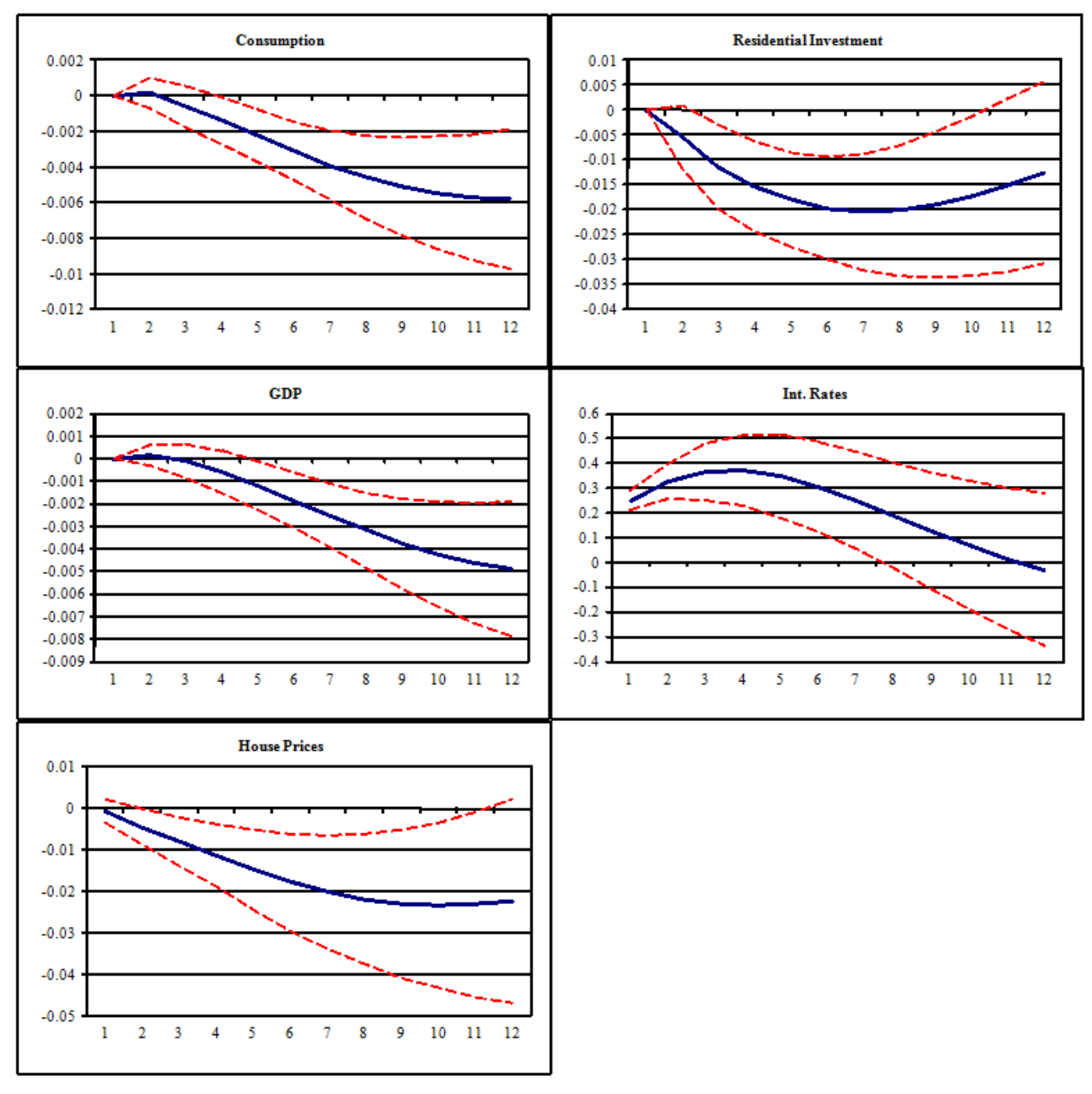

Figure 5: Impulse response from VAR, monetary policy shock. 


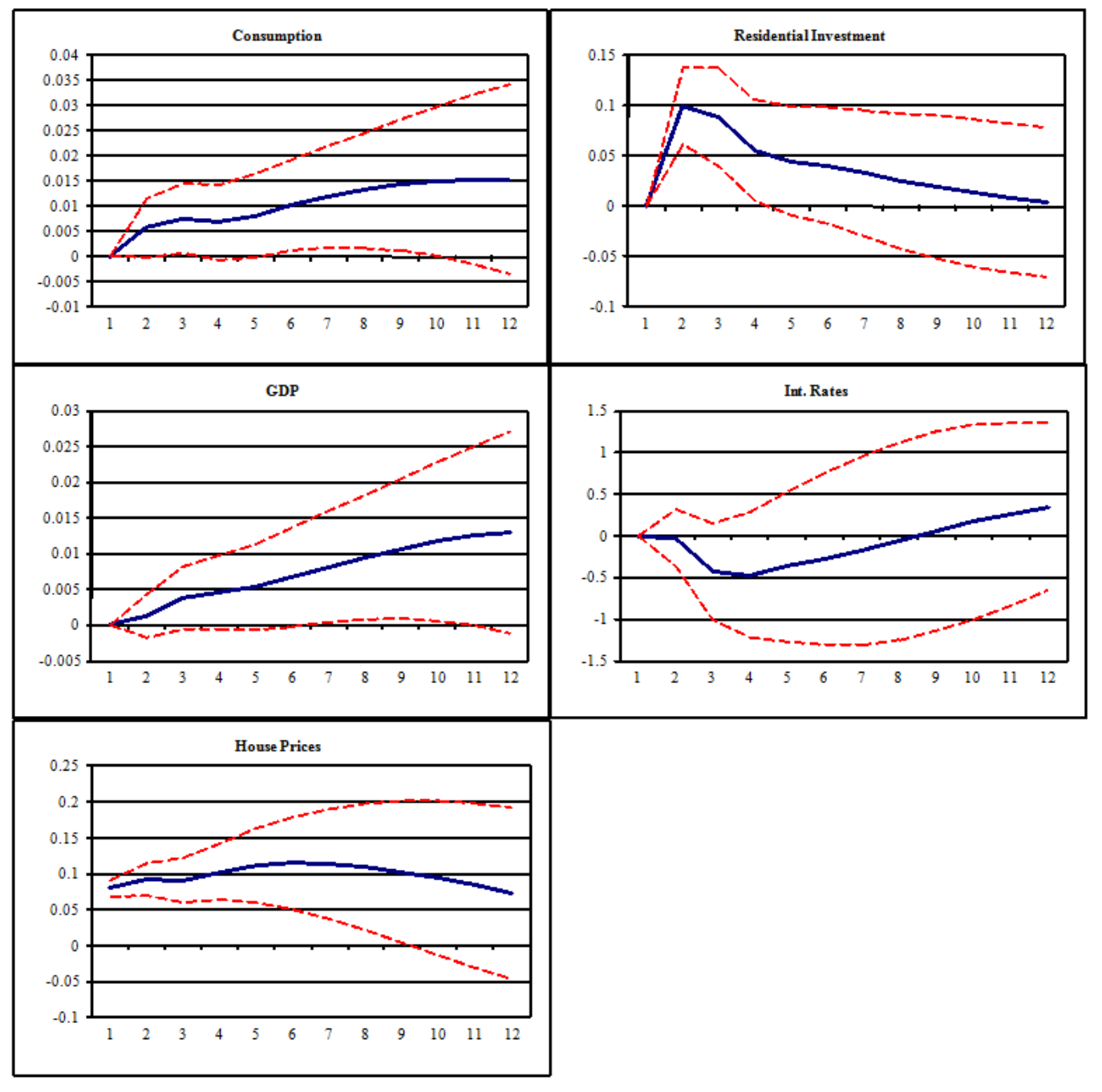

Figure 6: Impulse response from VAR, housing demand shock. 

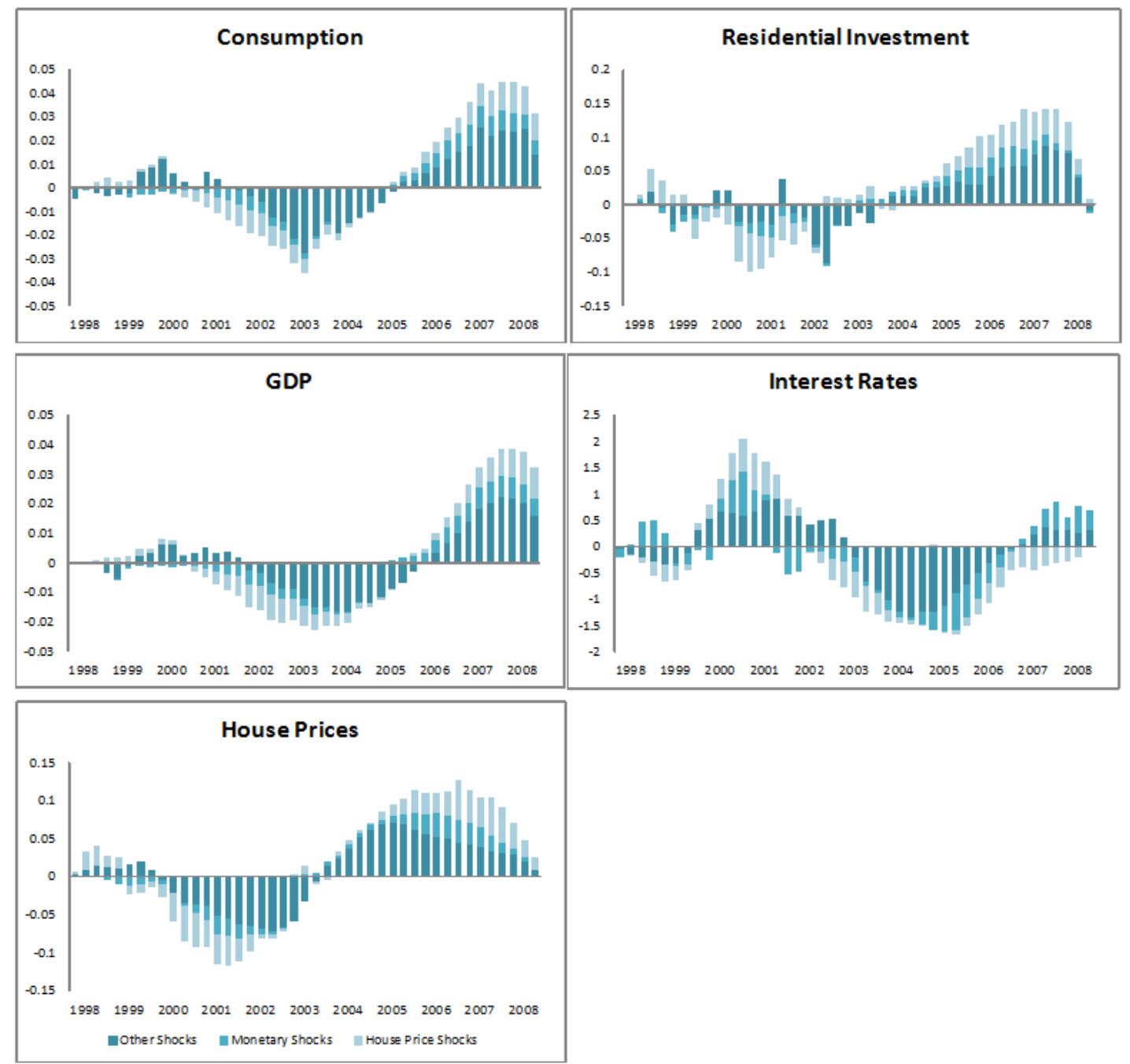

Figure 7: Historical decomposition from the VAR. 

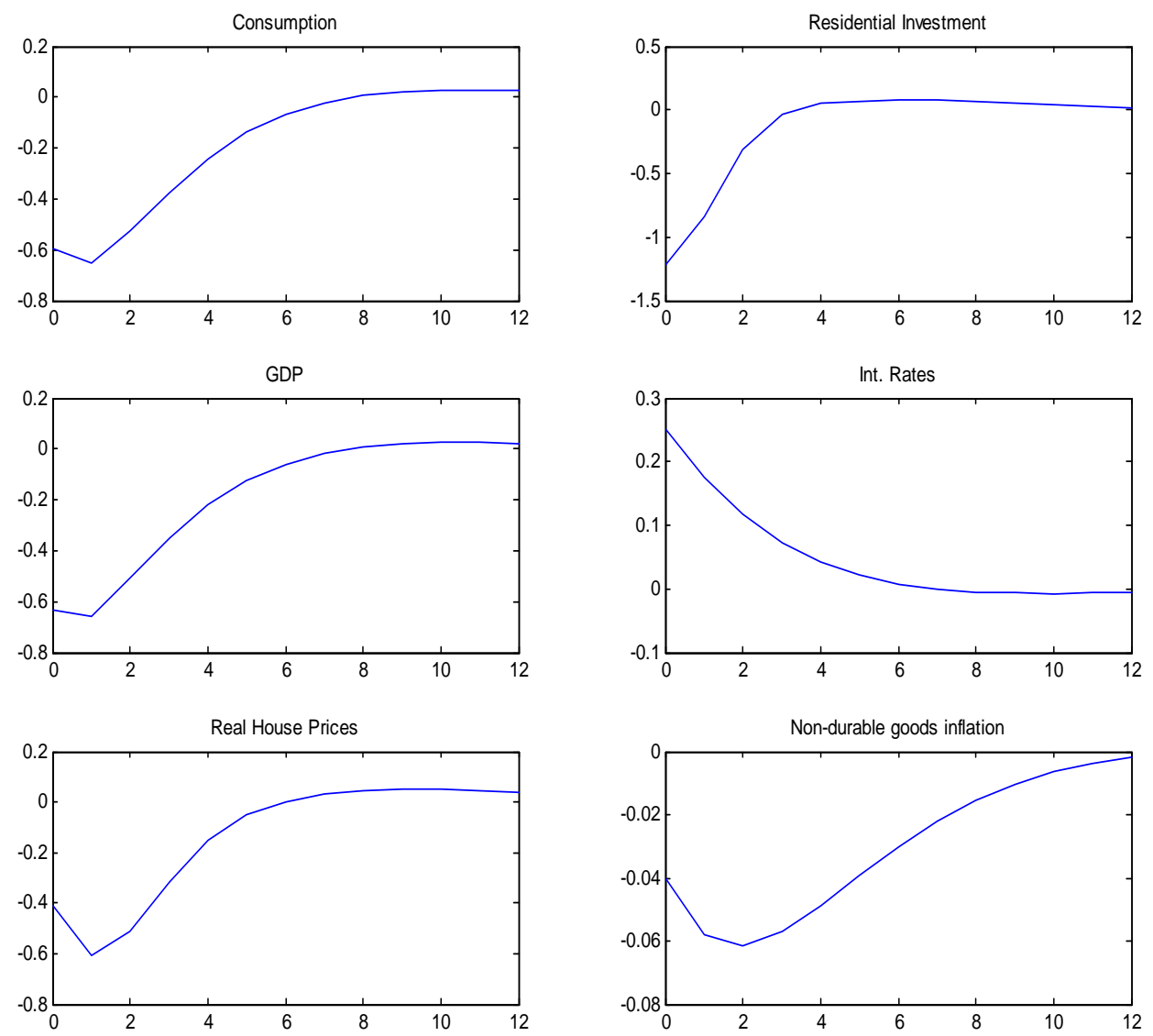

Figure 8: Impulse response to monetary policy shock. 

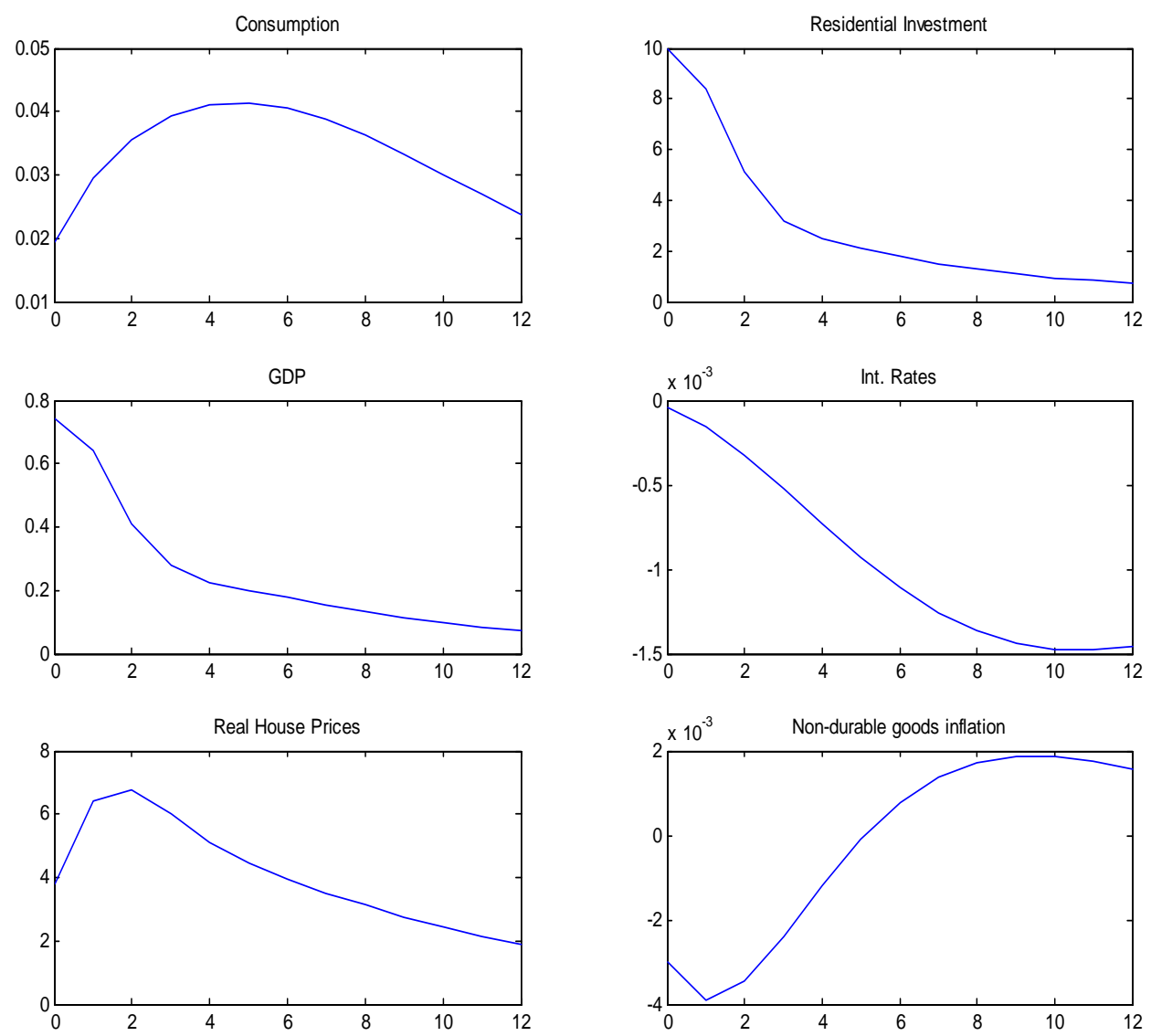

Figure 9: Impulse response to a housing preference shock. 

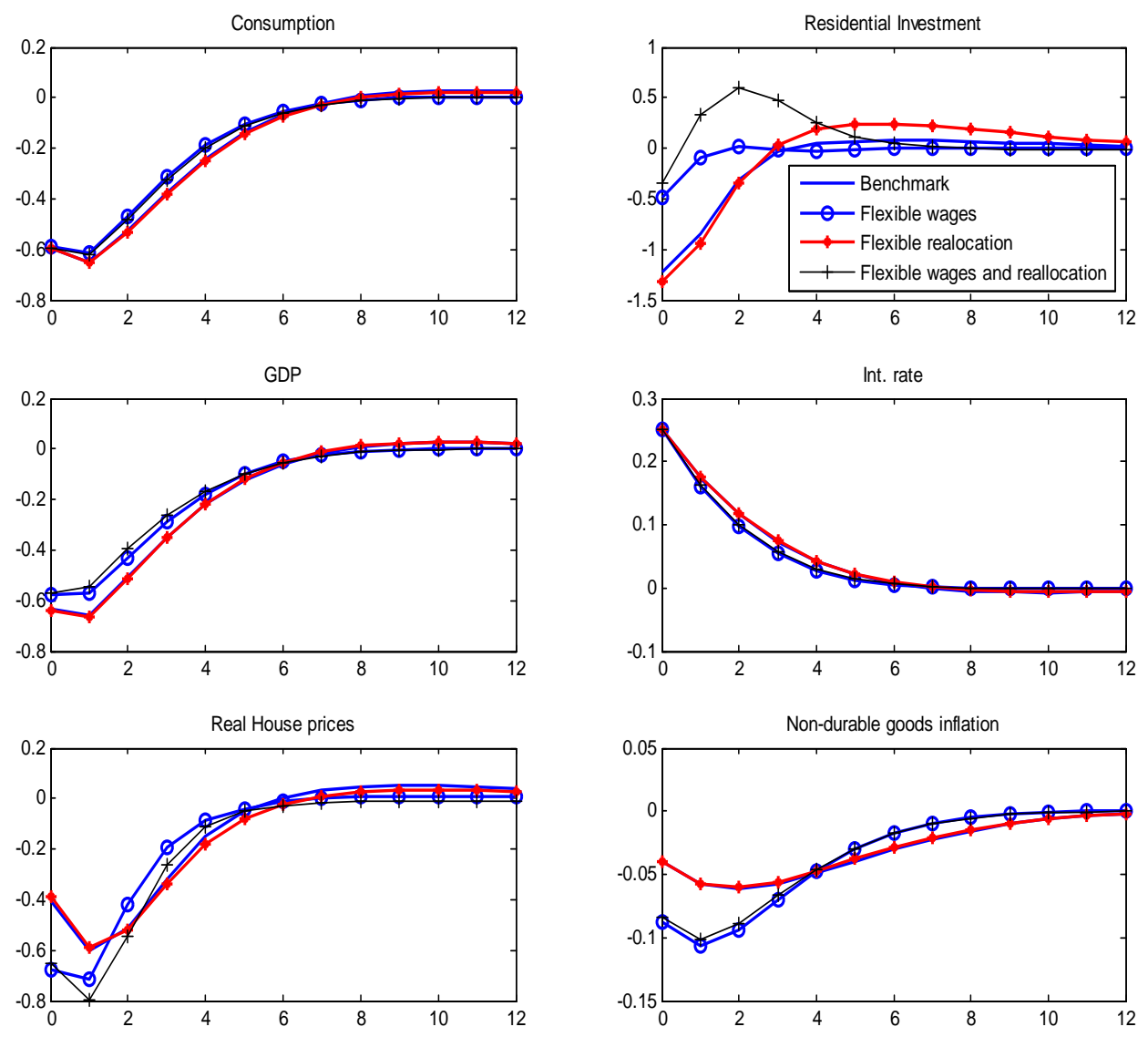

Figure 10: Impulse response to a monetary shock. The role of labor market frictions. 

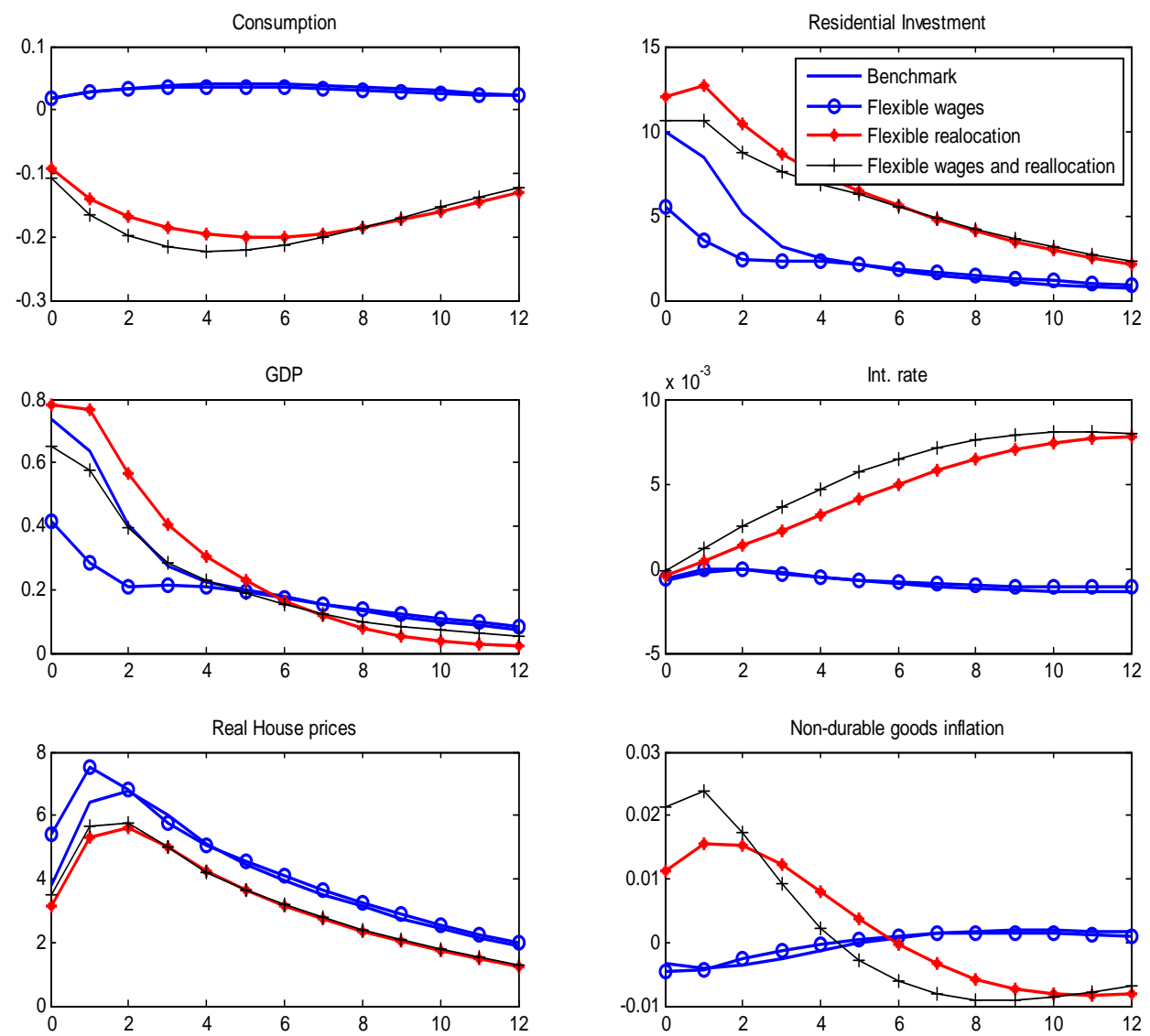

Figure 11: Impulse response to a housing preference shock. The role of labor market frictions. 

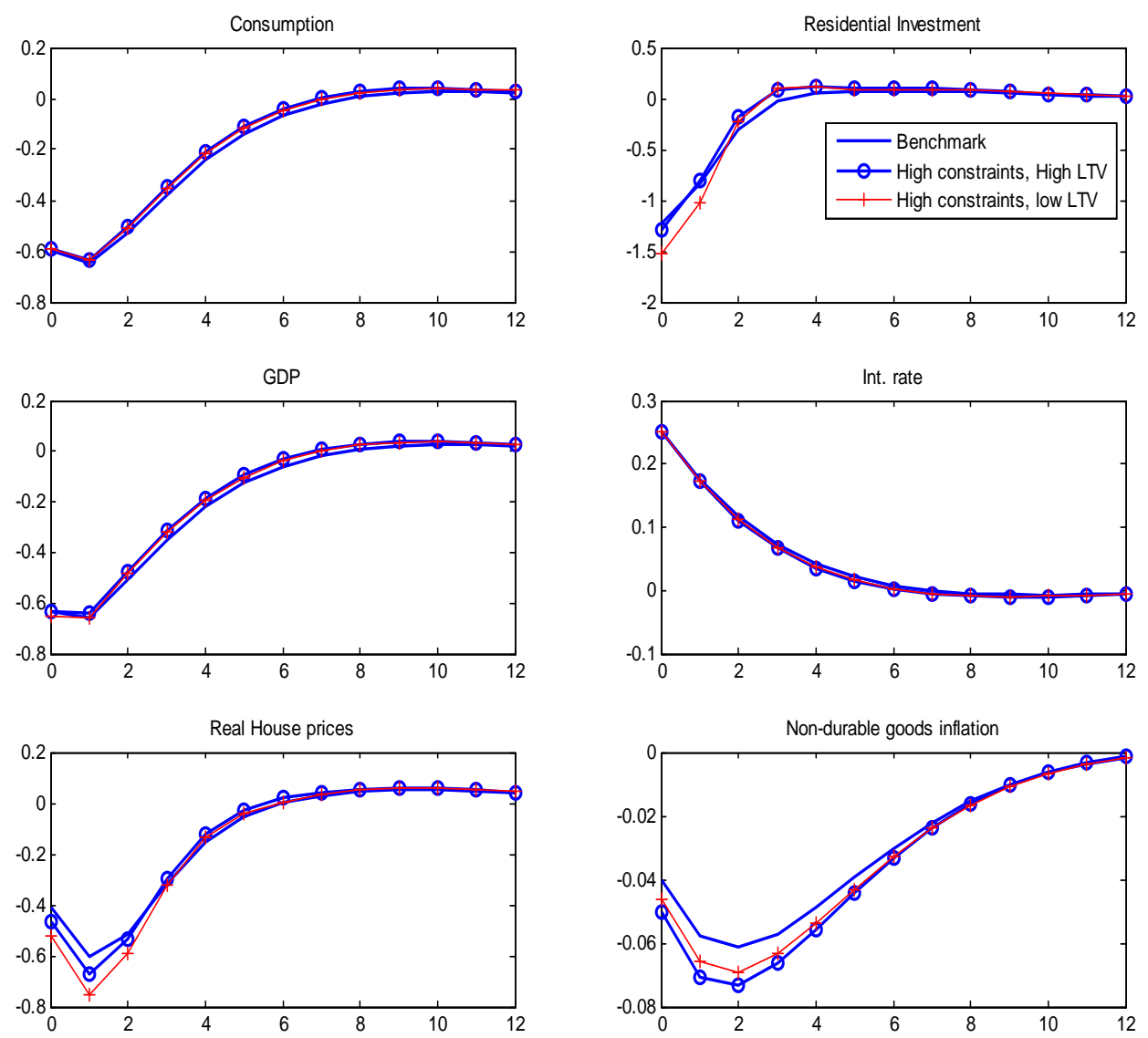

Figure 12: Impulse response to a monetary shock. The role of financial frictions. 

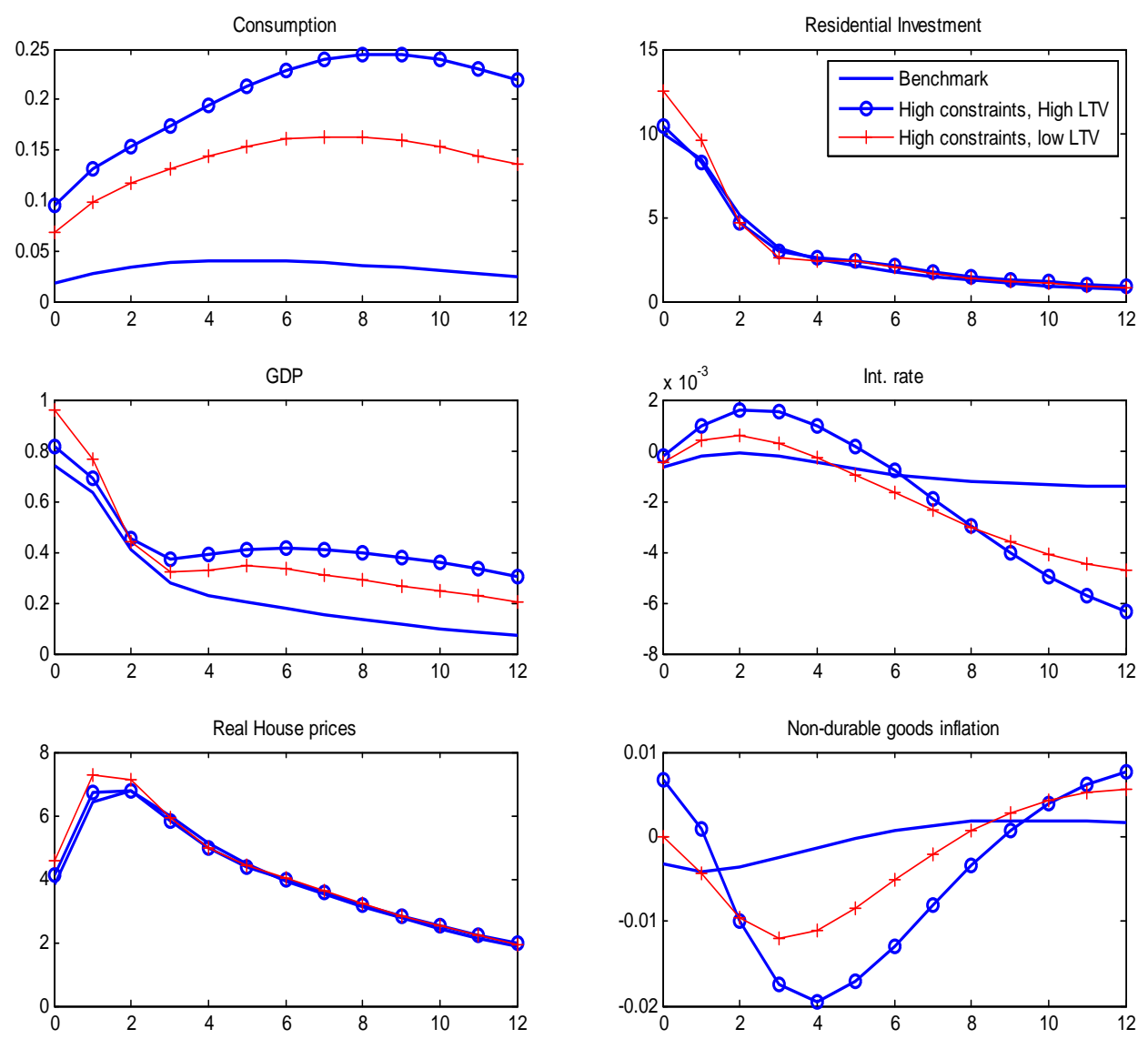

Figure 13: Impulse response to a housing preference shock. The role of financial frictions. 

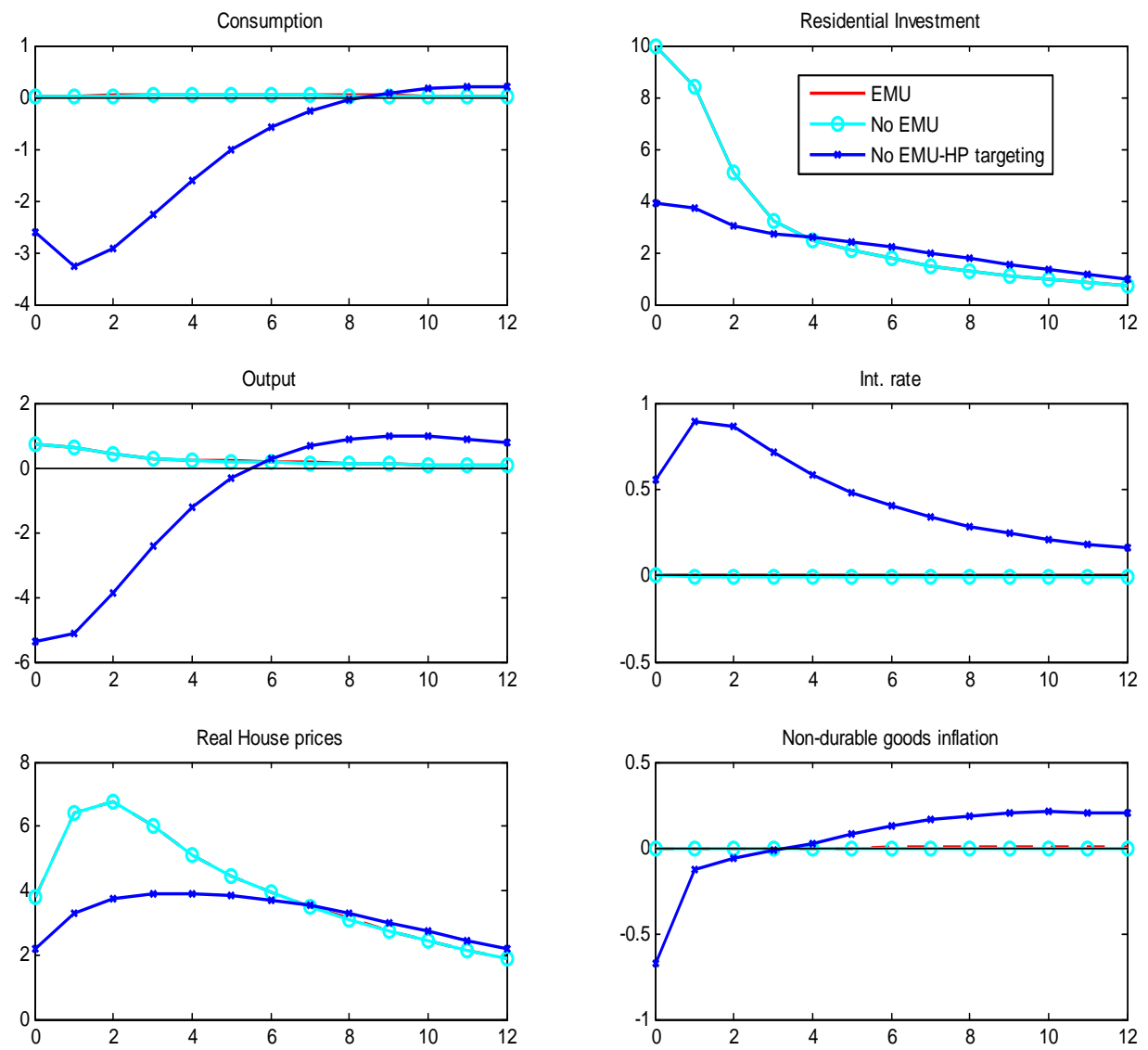

Figure 14: Impulse response to housing preference shock. The effects of belonging to the EMU. 

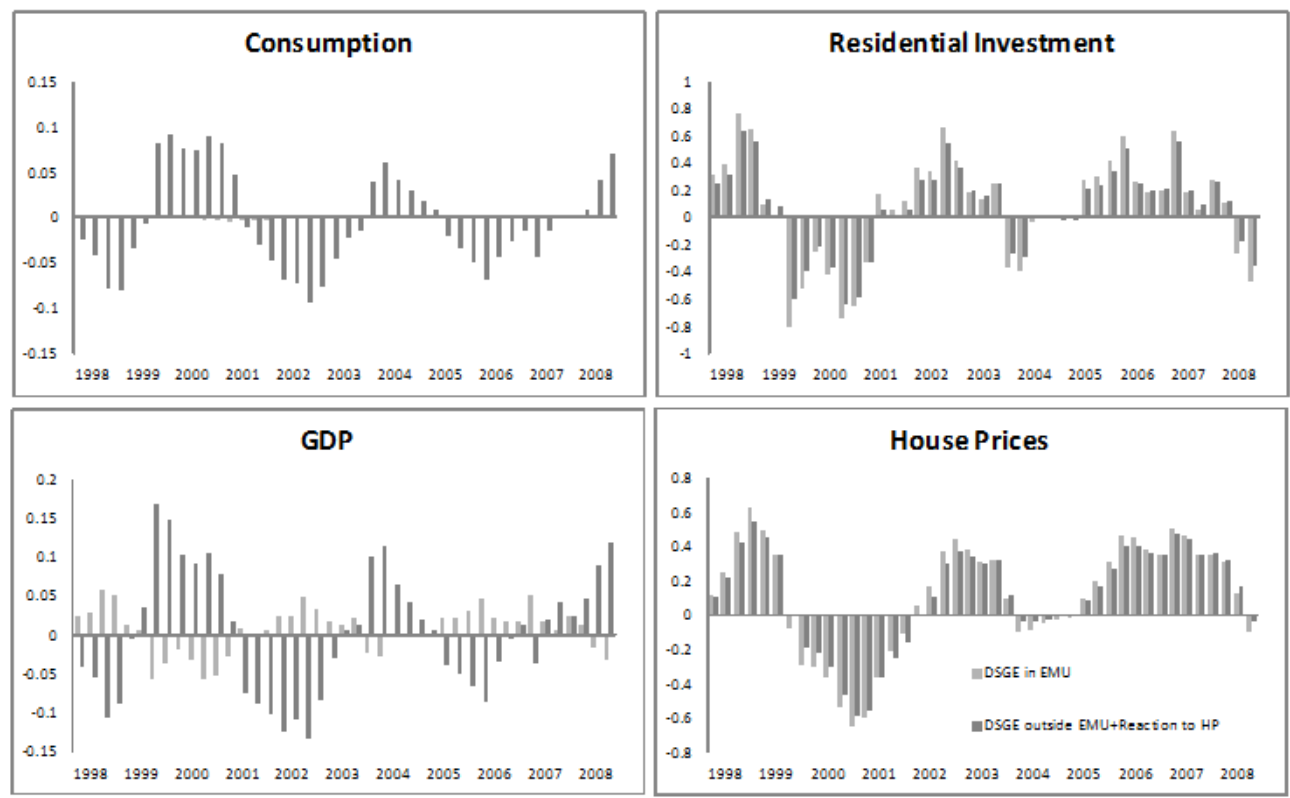

Figure 15: Counterfactual simulation of the model. 